\title{
CARBONATES IN SKELETON-POOR SEAS: NEW INSIGHTS FROM CAMBRIAN AND ORDOVICIAN STRATA OF LAURENTIA
}

\author{
SARA B. PRUSS, ${ }^{*}$ SETH FINNEGAN, ${ }^{2}$ WOODWARD W. FISCHER,${ }^{3}$ and ANDREW H. KNOLL ${ }^{4}$ \\ ${ }^{1}$ Department of Geosciences, Smith College, Northampton, Massachusetts 01063, USA; ${ }^{2}$ Department of Geological and Environmental Sciences, Stanford University, \\ 450 Serra Mall, Stanford, California 94022, USA; ${ }^{3}$ Division of Geological and Planetary Sciences, California Institute of Technology, Pasadena, California 91125, USA; \\ ${ }^{4}$ Department of Organismic and Evolutionary Biology, Harvard University, Cambridge, Massachusetts 02138, USA \\ e-mail: spruss@smith.edu
}

\begin{abstract}
Calcareous skeletons evolved as part of the greater Ediacaran-Cambrian diversification of marine animals. Skeletons did not become permanent, globally important sources of carbonate sediment, however, until the Ordovician radiation. Representative carbonate facies in a Series $3(510$ $501 \mathrm{Ma})$ Cambrian to Tremadocian succession from western Newfoundland, Canada, and Ordovician successions from the Ibex area, Utah, USA, show that, on average, Cambrian and Tremadocian carbonates contain much less skeletal material than do post-Tremadocian sediments. Petrographic point counts of skeletal abundance within facies and proportional facies abundance in measured sections suggest that later Cambrian successions contain on average $<\mathbf{5} \%$ skeletal material by volume, whereas the skeletal content of post-Tremadocian Ordovician sections is closer to $\sim 15 \%$. A compilation of carbonate stratigraphic sections from across Laurentia confirms that post-Tremadocian increase in skeletal content is a general pattern and not unique to the two basins studied. The long interval ( $\sim \mathbf{4 0}$ myr) between the initial Cambrian appearance of carbonate skeletons and the subsequent Ordovician diversification of heavily skeletonized organisms provides an important perspective on the Ordovician radiation. Geochemical data increasingly support the hypothesis that later Cambrian oceans were warm and, in subsurface water masses, commonly dysoxic to anoxic. We suggest that surface waters in such oceans would have been characterized by relatively low saturation states for calcite and aragonite. Mid-Ordovician cooling would have raised oxygen concentrations in subsurface water masses, establishing more highly oversaturated surface waters. If correct, these links could provide a proximal trigger for the renewed radiation of heavily skeletonized invertebrates and algae.
\end{abstract}

\section{INTRODUCTION}

Carbonate skeletons emerged as part of the initial diversification of animals. Lightly mineralized $\mathrm{CaCO}_{3}$ skeletons first appeared in reef environments near the end of the Ediacaran Period (Grotzinger et al., 2000; Wood et al., 2002), and skeletonized benthos expanded markedly during the subsequent early Cambrian radiation (Bengston and Conway Morris, 1992). It has been suggested that early Cambrian radiation of skeletonized organisms shifted both the mechanisms and loci of carbonate production from those typical of Proterozoic oceans (i.e., abiotic or biologically induced precipitation out of the water column or on the seafloor) to a Paleozoic regime dominated by skeletal biomineralization in shelf and platform environments (e.g., Zeebe and Westbroek, 2003). Despite the early appearance of skeletal biomineralization, however, the diversity and abundance of calcified skeletons remained low in Cambrian oceans, especially following the late early Cambrian collapse of archaeocyathids. During the subsequent Ordovician radiation, new skeletal taxa appeared and many groups that had

* Corresponding author.

Copyright (C) 2010, SEPM (Society for Sedimentary Geology) originated earlier diversified markedly. Prominent among these were heavily calcified taxa, including corals, bryozoans, rhynchonelliform brachiopods, lithistid sponges, echinoderms, and dasycladalean algae. The diversification of these groups, long after the origins of both their general body plans and the biochemistry required for skeletal biomineralization, raises important questions about both early Phanerozoic modes of carbonate deposition and the controls on CambroOrdovician animal and algal evolution.

In this study, we examine the changing contribution of mineralized skeletons to carbonate deposits from the later Series 2 (521-510 Ma) and Series 3 Cambrian aftermath of archaeocyathid extinction to the Ordovician diversification of heavily skeletonized marine organisms. In previous work, Li and Droser $(1997,1999)$ showed that in the Ibex Area of western Utah, shell beds increased in thickness and abundance across the Ibexian-Whiterockian boundary (late Early-Middle Ordovician). These observations imply an increasing proportion of skeletal material in carbonate-rich sedimentary systems, but leave open the broader questions of skeletal abundance across facies and the geographic distribution of observed changes. To test whether this pattern documents an overall transition in carbonate sedimentation, we gathered evidence at three scales: point-counts of representative thin sections from western Newfoundland and the Ibex area of western Utah; estimates of proportional volumes of skeletal carbonate in measured sections from these two areas; and a meter-scale compilation of carbonate lithostratigraphy from multiple sections spanning the Cambrian and Ordovician of Laurentia. These data serve as a test of $\mathrm{Li}$ and Droser's $(1997,1999)$ hypothesis, as they encompass multiple volumetrically significant facies including, but not limited to, shell beds. All abundance data from the sedimentary record must be interpreted with caveats of sampling and preservation firmly in mind. Nonetheless, our results support the notion that the skeletal contribution to shallow-subtidal carbonate sediments did increase, possibly more than fivefold, between the Furongian and Middle Ordovician. This pattern cannot easily be accounted for by common preservation or paleoenvironmental biases; further testing will reveal the relative importance of these biases. Ultimately, the quantification of skeletal contributions to Cambro-Ordovician carbonate accumulation sheds new light on previously identified changes in the nature of the carbon cycle between the Cambrian and subsequent periods.

\section{GEOLOGIC SETTING}

During Cambro-Ordovician time, Laurentia lay over the equator (Smith, 2001; Hodych et al., 2004), largely covered by epeiric seas (Fig. 1). Extensive carbonate platforms developed on its northern, southern, and western margins; in some areas, Cambrian carbonate strata alone attain thicknesses near $2.5 \mathrm{~km}$ (e.g., Ginsberg, 1982; Montañez and Droser, 1991; Osleger and Montañez, 1996). Our samples come from two regions. The Series 3-Furongian (Cambrian) 


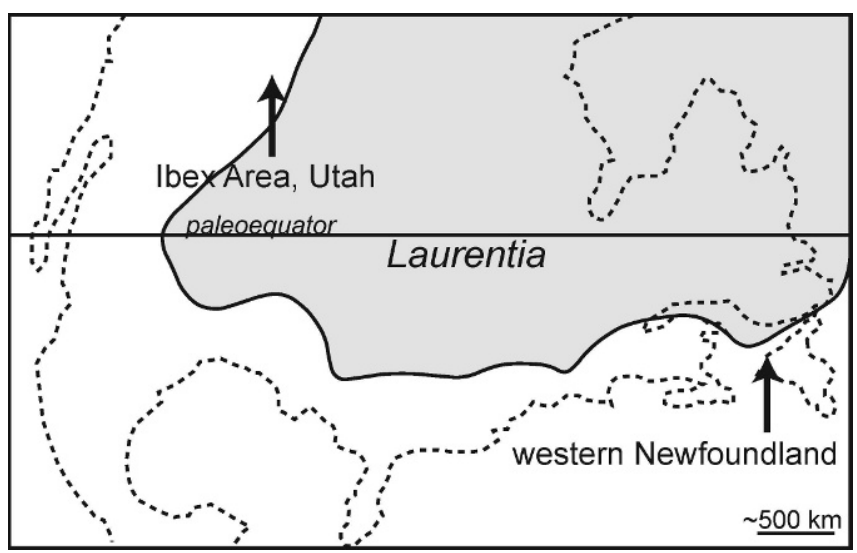

FIGURE 1-Map of Laurentia with western Newfoundland and Ibex Area, Utah, indicated by arrows. Dashed line $=$ Modern North America; gray shading $=$ paleocontinent.

Port au Port and Lower-Middle Ordovician St. George groups, exposed in western Newfoundland, were deposited on the southeastern margin of Laurentia. Cambrian and Ordovician carbonates of the Ibex area, Utah, accumulated at a similar latitude along its western margin.

\section{Western Newfoundland, Canada}

During Cambrian-Ordovician, autochthonous carbonate-siliciclastic strata accumulated on a shallow platform in western Newfoundland. A long hiatus separates the lower Cambrian Labrador Group from the overlying Series 3-Furongian Port au Port Group. Lower Ordovician strata of the St. George Group cap the succession on the Port au Port Peninsula. At the study site, Cambro-Ordovician strata are well exposed and have been extensively studied along two arms of a broad, gently dipping anticline that makes up the south-facing shore of the Port au Port Peninsula (e.g., Pratt and James, 1982, 1986; Chow and James, 1987; Knight and James, 1987; James et al., 1989; Cowan and James, 1993). Biostratigraphic and chemostratigraphic constraints on Cambrian strata include the Series 3 Bolaspidella through Furongian Elvinia trilobite zones (e.g., Westrop, 1992; Saltzman et al., 2004) and the geographically widespread SPICE C-isotopic event (Saltzman et al., 2004). Lower Ordovician strata of the St. George Group preserve biostratigraphically well-constrained assemblages of conodonts ( $\mathrm{Ji}$ and Barnes, 1994) and gastropods (Rohr et al., 2001).

The Series 3 March Point Formation and Series 3-Furongian Petit Jardin Formation make up the Port au Port Group ( 190 meters; Fig. 2). Cambrian carbonates of western Newfoundland contain very few skeletal carbonates, with a few intervals of trilobite hash representing the only significant fossil accumulations exposed in the field. In contrast, oolites, microbial buildups, calcisiltites, and micrites are common, deposited in environments ranging from deep subtidal to peritidal.

The Lower Ordovician St. George Group consists (from bottom to top) of the Watts Bight, Boat Harbour, Catoche, and Aguathuna Formations (Knight and James, 1987). The majority of the St. George Group was deposited in shallow subtidal to peritidal settings during an interval with little siliciclastic input. Along the south-facing shore of the Port au Port Peninsula, complete sections of the Watts Bight $(\sim 70 \mathrm{~m})$ and Boat Harbour $(\sim 150 \mathrm{~m})$ Formations are exposed and we examined these units in outcrop and thin section. The Lower Ordovician Catoche Formation is exposed at the nearby Port au Choix and Point Riche Peninsulas, and the Lower Ordovician Aguathuna Formation crops out near East Bay on the Port au Port Peninsula (Knight and James, 1987).

\section{Ibex Area, Western Utah, USA}

The Ibex Area of Utah, in the Basin and Range region of the western United States, was the site of nearly continuous carbonate sedimentation from Series 3 of the Cambrian through Middle Ordovician time. Ordovician strata of the Pogonip Group are particularly well exposed and well studied in the Ibex region of western Utah and adjacent areas of eastern Nevada (Hintze, 1973; Ross et al., 1997) and are biostratigraphically well constrained by trilobites and conodonts (Miller et al., 2003). The Pogonip Group comprises the Lower Ordovician $($ Ibexian $=$ Tremadocian-Floian) Notch Peak Formation, House Limestone, Fillmore Formation, and Wah Wah Limestone (Fig. 2), which generally record mixed carbonate-siliciclastic sedimentation on a broad, shallow mixed carbonate-siliciclastic ramp (Ross, 1977; Ross et al., 1989) and the Middle Ordovician (Whiterockian = uppermost Floian [upper Lower Ordovician]-Darriwilian [upper Middle Ordovician]) Juab Limestone, Kanosh Shale, and Lehman Formation, which record the development of a carbonate platform rimmed by basinward oncoid shoals. Above the Lehman, the late Middle Ordovician and early Upper Ordovician are represented by thick regional quartzites. Although pure carbonate sedimentation resumes in the Upper Ordovician, Upper Ordovician-Silurian units are pervasively dolomitized (fabric destructive), and hence their fabric was not examined for this study.

The Notch Peak Formation $(150 \mathrm{~m})$ and House Limestone $(210 \mathrm{~m})$ are dominated by carbonate mudstones and dolostones with common stromatolites and other small microbial buildups, which record generally shallow subtidal to peritidal sedimentation. Flat pebble conglomerates and thin trilobite-lingulid-echinoderm shell beds are present but are uncommon compared to overlying units (Li and Droser, 1999). The base of the Fillmore Formation (325 m) marks a clastic influx and a significant change in depositional mode. The lower 200 meters of the Fillmore are dominated by flat-pebble conglomerates containing locally abundant but highly abraded skeletal grains and are interbedded with sparsely fossiliferous shales at decimeter-to-meter scales. Beginning in the upper Fillmore Formation and continuing into the Wah Wah Limestone (61 m), wackestones, packstones, and skeletal grainstones are increasingly abundant. Small sponge-microbial buildups are also common in several beds within the upper Fillmore Formation and Wah Wah Limestone (Johns, 1995), but microbial facies overall are a volumetrically minor component of these units.

The Middle Ordovician is represented by the Juab Limestone $(55 \mathrm{~m})$, Kanosh Shale $(\sim 162 \mathrm{~m})$, and Lehman Formation $(\sim 35 \mathrm{~m})$. The Juab Limestone is similar to the underlying Wah Wah in overall facies architecture, recording cyclic, deep-to-shallow, subtidal sedimentation, and it also contains abundant shell beds and common sponge-microbial buildups (Li and Droser, 1999; Finnegan and Droser, 2005). The transition to the lower Kanosh Shale represents significant local deepening and the onset of anoxic conditions related to the development of shelf-edge oncoid shoals in central Nevada (McDowell, 1987; Ross et al., 1989; Boyer and Droser, 2003). A shallowing trend though the upper Kanosh Shale culminates in the Lehman Formation, which is composed primarily of shallow subtidal-to-peritidal carbonate mudstones and packstones.

\section{METHODS}

As noted above, Cambro-Ordovician carbonate strata were analyzed at three nested scales. For a variety of units in Newfoundland and Utah, thin sections of representative peritidal-to-shallow subtidal carbonate facies were examined to determine how much skeletal material contributed to each carbonate lithology. Mudstones, wackestones, packstones, skeletal grainstones, oolites, and microbialites were the most common facies in outcrop, and several examples of each were analyzed in thin section. Although a variety of lithofacies exist in 


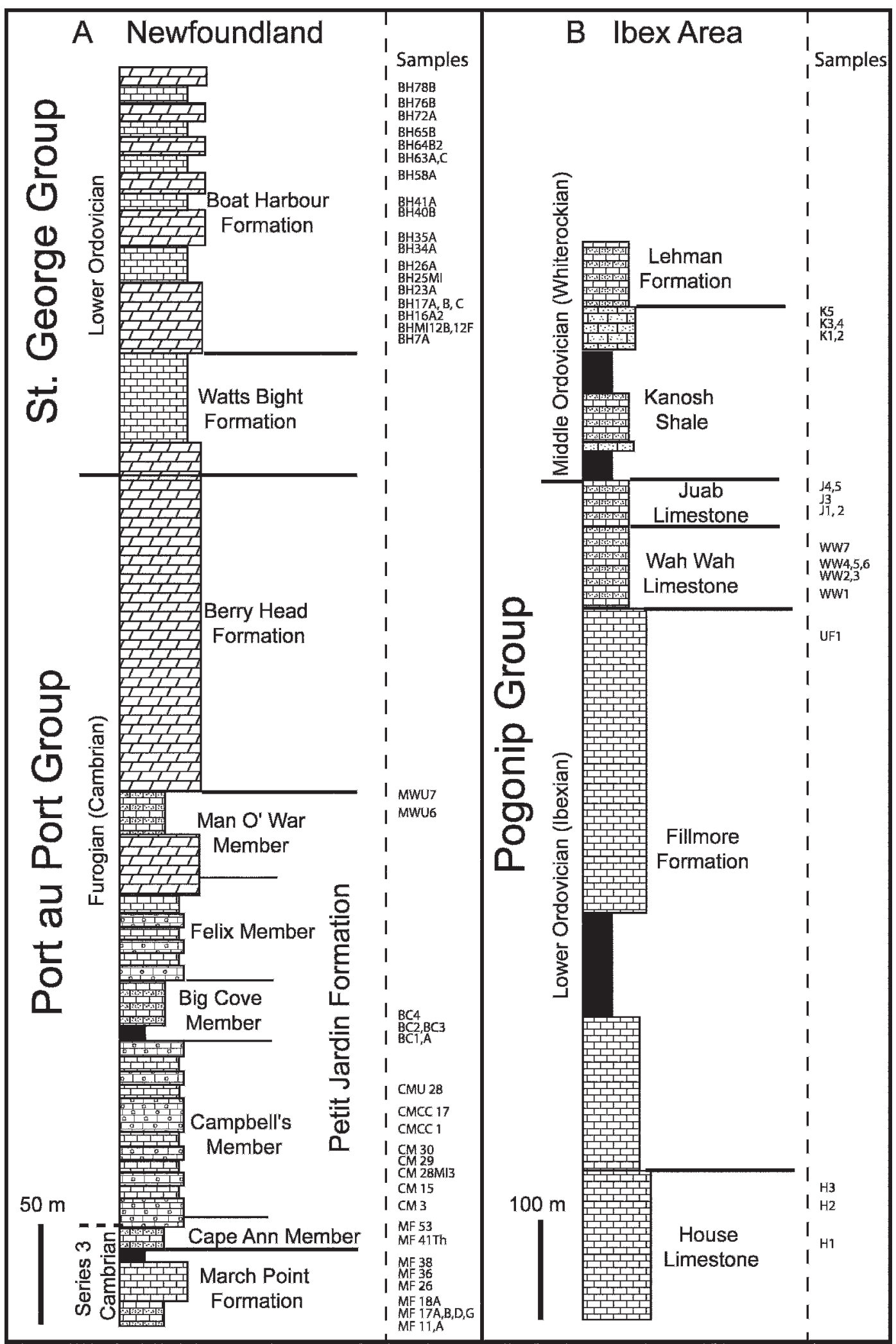

FIGURE 2-Stratigraphic columns of sections examined in (A) western Newfoundland, and (B)Ibex Area, Utah. Samples analyzed in thin section are listed stratigraphically and point-count identifications are shown in Table 1.

western Newfoundland and the Ibex area of Utah, the thin sections described here provide broad coverage of the skeletal contribution to the most common carbonate lithofacies through the study interval and allowed us to compare data generated at each locality most directly. We examined 48 thin sections from Cambrian and Lower Ordovician carbonates of western Newfoundland and 25 thin sections from LowerMiddle Ordovician carbonates from the Ibex area of Utah (Fig. 2). Although these two stratigraphic successions do not provide an ideal 
TABLE 1-Point count data from mid-Cambrian (Series 3) to Lower Ordovician strata, western Newfoundland, and Lower-Upper Ordovician strata, Utah and Nevada. Tables show abundance of identified carbonate components counted in thin section. Dunham $=$ Dunham classification assigned to each sample; Spar $=$ sparry carbonate cement; Microb = microbial microfacies; FP = flat pebble.

\begin{tabular}{|c|c|c|c|c|c|c|c|c|c|c|c|c|c|c|c|c|c|c|c|}
\hline Sample & Dunham & $\mathrm{m}$ Age & \multicolumn{2}{|c|}{ Formation } & Micrite & Spar & Ooid & Trilo & Oncoid & Echino & Brach & & Microb & FP $\quad \mathrm{Ur}_{1}$ & Unident & Mollusk & Peloids & & Other \\
\hline MF11 & GS & $\mathrm{S} 3$ & \multicolumn{2}{|l|}{ March } & 41 & 85 & 0 & 9 & 5 & 16 & 1 & & 0 & 5 & 4 & 0 & 0 & & 34 \\
\hline MF11A & GS & S3 & March & & 39 & 24 & 0 & 33 & 0 & 0 & 0 & & 0 & 0 & 0 & 0 & 0 & & 104 \\
\hline MF17 & FP & $\mathrm{S} 3$ & March & & 19 & 54 & 0 & 6 & 0 & 0 & 0 & & 0 & 122 & 14 & 0 & 0 & & 0 \\
\hline MF17B & GS & S3 & March & & 83 & 36 & 0 & 14 & 0 & 2 & 2 & & 0 & 74 & 1 & 0 & 0 & & 8 \\
\hline MF17D & GS & S3 & March & & 92 & 95 & 0 & 3 & 0 & 1 & 0 & & 0 & 0 & 0 & 0 & 0 & & 9 \\
\hline MF17G & GS & S3 & March & & 106 & 19 & 0 & 23 & 47 & 2 & 0 & & 0 & 0 & 3 & 0 & 0 & & 1 \\
\hline MF18A & GS & S3 & March & & 95 & 6 & 0 & 38 & 0 & 0 & 1 & & 0 & 57 & 1 & 0 & 0 & & 2 \\
\hline MF26 & $\mathrm{MS} / \mathrm{W}$ & S3 & March & & 200 & 0 & 0 & 0 & 0 & 0 & 0 & & 0 & 0 & 0 & 0 & 0 & & 0 \\
\hline MF36 & FP & S3 & March & & 53 & 23 & 8 & 0 & 0 & 0 & 0 & & 3 & 113 & 0 & 0 & 0 & & 0 \\
\hline MF38 & GS & S3 & March & & 75 & 71 & 1 & 21 & 5 & 4 & 0 & & 0 & 11 & 6 & 6 & 0 & & 0 \\
\hline MF41Th & MIC & $\mathrm{S} 3$ & Cape An & & 151 & 14 & 0 & 0 & 0 & 0 & 0 & & 35 & 0 & 0 & 0 & 0 & & 0 \\
\hline MF53 & $\mathrm{O}$ & $\mathrm{S} 3$ & Cape An & & 4 & 102 & 94 & 0 & 0 & 0 & 0 & & 0 & 0 & 0 & 0 & 0 & & 0 \\
\hline $\mathrm{CMCCl}$ & $\mathrm{MIC} / \mathrm{C}$ & $\mathrm{FU}$ & Campbell & & 114 & 8 & 0 & 0 & 0 & 30 & 0 & & 43 & 0 & 5 & 0 & 0 & & 0 \\
\hline $\mathrm{CMCC} 17$ & $\mathrm{O}$ & $\mathrm{FU}$ & Campbell & & 11 & 53 & 134 & 0 & 0 & 0 & 0 & & 0 & 0 & 0 & 0 & 0 & & 0 \\
\hline CM3 & FP & $\mathrm{FU}$ & Campbell & & 122 & 55 & 1 & 0 & 0 & 0 & 0 & & 0 & 12 & 0 & 0 & 0 & & 0 \\
\hline CM15 & GS & $\mathrm{FU}$ & Campbel & & 3 & 98 & 82 & 0 & 2 & 15 & 0 & & 0 & 0 & 0 & 0 & 0 & & 0 \\
\hline CM28MI3 & $\mathrm{MIC}$ & $\mathrm{FU}$ & Campbell & & 148 & 8 & 1 & 0 & 0 & 7 & 0 & & 35 & 0 & 1 & 0 & 0 & & 0 \\
\hline CM29 & $\mathrm{MS} / \mathrm{W}$ & $\mathrm{FU}$ & Campbell & & 200 & 0 & 0 & 0 & 0 & 0 & 0 & & 0 & 0 & 0 & 0 & 0 & & 0 \\
\hline CM30 & MIC & $\mathrm{FU}$ & Campbell & & 78 & 30 & 0 & 0 & 0 & 0 & 0 & & 92 & 0 & 0 & 0 & 0 & & 0 \\
\hline CMU28 & GS & $\mathrm{FU}$ & Campbell & & 140 & 3 & 32 & 2 & 0 & 11 & 0 & & 0 & 0 & 4 & 0 & 0 & & 8 \\
\hline $\mathrm{BCl}$ & $\mathrm{MS} / \mathrm{W}$ & FU & Big Cove & & 200 & 0 & 0 & 0 & 0 & 0 & 0 & & 0 & 0 & 0 & 0 & 0 & & 0 \\
\hline $\mathrm{BClA}$ & GS & $\mathrm{FU}$ & Big Cove & & 64 & 1 & 0 & 24 & 0 & 0 & 0 & & 0 & 108 & 2 & 0 & 0 & & 1 \\
\hline $\mathrm{BC} 2$ & GS & $\mathrm{FU}$ & Big Cove & & 123 & 2 & 0 & 45 & 0 & 0 & 0 & & 0 & 20 & 0 & 0 & 0 & & 10 \\
\hline $\mathrm{BC} 3$ & GS & $\mathrm{FU}$ & Big Cove & & 79 & 10 & 0 & 30 & 55 & 0 & 1 & & 0 & 0 & 0 & 0 & 0 & & 27 \\
\hline MWU6 & $\mathrm{O}$ & $\mathrm{FU}$ & Man o' $\mathrm{V}$ & & 62 & 34 & 87 & 1 & 0 & 8 & 0 & & 0 & 0 & 8 & 0 & 0 & & 0 \\
\hline MWU7 & $\mathrm{MS} / \mathrm{W}$ & $\mathrm{FU}$ & Man o' Y & & 192 & 8 & 0 & 0 & 0 & 0 & 0 & & 0 & 0 & 0 & 0 & 0 & & 0 \\
\hline BH7A & $\mathrm{FP}$ & TR & B. Harbo & & 155 & 20 & 0 & 0 & 0 & 1 & 0 & & 0 & 10 & 0 & 0 & 7 & & 7 \\
\hline BH16A2 & PS & TR & B. Harbo & & 125 & 30 & 0 & 0 & 0 & 0 & 0 & & 0 & 15 & 0 & 1 & 20 & & 9 \\
\hline BH17A & PS & TR & B. Harbo & & 19 & 91 & 0 & 4 & 2 & 24 & 0 & & 0 & 2 & 5 & 3 & 32 & & 18 \\
\hline BHMI7B & MS & TR & B. Harbo & & 17 & 35 & 0 & 0 & 0 & 0 & 0 & & 137 & 0 & 0 & 0 & 11 & & 0 \\
\hline BH17C & MS & TR & B. Harbo & & 93 & 31 & 0 & 1 & 0 & 0 & 0 & & 0 & 4 & 0 & 0 & 19 & & 52 \\
\hline BHMI12B & $\mathrm{MIC}$ & TR & B. Harbo & & 89 & 63 & 0 & 0 & 0 & 0 & 0 & & 19 & 0 & 1 & 9 & 19 & & 0 \\
\hline $\mathrm{BH} 12 \mathrm{~F}$ & GS & TR & B. Harbo & & 119 & 68 & 0 & 3 & 0 & 0 & 0 & & 0 & 0 & 2 & 0 & 8 & & 0 \\
\hline BH23A & GS & TR & B. Harbo & & 97 & 7 & 0 & 1 & 0 & 1 & 2 & & 0 & 6 & 3 & 2 & 14 & & 67 \\
\hline BH25MI & $\mathrm{MIC}$ & TR & B. Harbo & & 152 & 3 & 0 & 0 & 0 & 0 & 0 & & 0 & 1 & 0 & 22 & 17 & & 5 \\
\hline BH26A & MS & TR & B. Harbo & & 132 & 4 & 0 & 0 & 0 & 0 & 0 & & 0 & 0 & 0 & 0 & 0 & & 64 \\
\hline BH34A & WS & TR & B. Harbo & & 142 & 13 & 0 & 0 & 0 & 2 & 0 & & 0 & 0 & 1 & 0 & 39 & & 3 \\
\hline BH35A & FP & TR & B. Harbo & & 23 & 56 & 33 & 0 & 0 & 0 & 0 & & 0 & 38 & 0 & 0 & 48 & & 2 \\
\hline BH40B & WS & TR & B. Harbo & & 34 & 63 & 0 & 0 & 0 & 1 & 0 & & 0 & 8 & 1 & 0 & 93 & & 0 \\
\hline BH41A & MIC & TR & B. Harbo & & 105 & 5 & 0 & 0 & 0 & 0 & 0 & & 0 & 0 & 3 & 0 & 0 & & 87 \\
\hline BH58A & WS & TR & B. Harbo & & 116 & 21 & 0 & 0 & 0 & 1 & 0 & & 0 & 18 & 2 & 0 & 29 & & 13 \\
\hline BH63A & $\mathrm{O}$ & TR & B. Harbo & & 27 & 49 & 107 & 0 & 0 & 0 & 0 & & 0 & 1 & 0 & 0 & 11 & & 5 \\
\hline BH63C & $\mathrm{O}$ & TR & B. Harbo & & 42 & 56 & 42 & 0 & 0 & 0 & 0 & & 6 & 0 & 0 & 0 & 54 & & 0 \\
\hline BH64B2 & $\mathrm{MIC}$ & TR & B. Harbo & & 6 & 30 & 0 & 0 & 0 & 0 & 0 & & 150 & 0 & 0 & 0 & 0 & & 14 \\
\hline BH65B & $\mathrm{O}$ & TR & B. Harbo & & 38 & 59 & 73 & 1 & 1 & 5 & 0 & & 0 & 10 & 2 & 1 & 10 & & 0 \\
\hline BH72A & GS & TR & B. Harbo & & 122 & 53 & 0 & 0 & 0 & 0 & 0 & & 0 & 0 & 1 & 0 & 21 & & 3 \\
\hline $\mathrm{BH} 76 \mathrm{~B}$ & GS & TR & B. Harbo & & 23 & 57 & 0 & 6 & 0 & 14 & 0 & & 5 & 20 & 4 & 1 & 70 & & 0 \\
\hline BH78B & GS & TR & B. Harbo & & 40 & 54 & 1 & 1 & 0 & 11 & 0 & & 2 & 43 & 2 & 6 & 16 & & 24 \\
\hline Sample & Dunham & Age & Formation & Nuid & ia Uni & d.Alga & Brach. & Echino. & Gastro. & Biv. & Ostra. & Por. & Trilo. & . Unid & Spar & Micrite & ?Carb. & Intra. & Pel. \\
\hline H1 & MS & TR & House & 0 & & 0 & 0 & 0 & 0 & 0 & 0 & 0 & 0 & 0 & 18 & 182 & 0 & 0 & 0 \\
\hline $\mathrm{H} 2$ & MS & TR & House & 0 & & 0 & 0 & 2 & 0 & 0 & 0 & 0 & 4 & 0 & 2 & 188 & 0 & 0 & 8 \\
\hline H3 & MS & TR & House & 0 & & 0 & 0 & 0 & 0 & 0 & 0 & 0 & 0 & 0 & 0 & 200 & 0 & 0 & 0 \\
\hline L.NM1 & WS & TR & $\begin{array}{l}\text { Lower } \\
\text { Ninemile }\end{array}$ & 0 & & 0 & 30 & 0 & 0 & 0 & 0 & 0 & 10 & 10 & 16 & 138 & 0 & 0 & 0 \\
\hline L.NM2 & MS & TR & $\begin{array}{l}\text { Lower } \\
\text { Ninemile }\end{array}$ & 0 & & 0 & 0 & 0 & 0 & 0 & 0 & 0 & 6 & 2 & 6 & 188 & 0 & 0 & 2 \\
\hline LF1 & GS & TR & $\begin{array}{l}\text { Lower } \\
\text { Fillmore }\end{array}$ & 0 & & 0 & 0 & 2 & 0 & 0 & 0 & 0 & 4 & 2 & 0 & 58 & 94 & 0 & 40 \\
\hline $\mathrm{J} 1$ & PS & L.AR & Juab & 0 & & 0 & 0 & 2 & 0 & 0 & 0 & 0 & 26 & 4 & 12 & 158 & 0 & 2 & 0 \\
\hline $\mathrm{J} 2$ & WS & L.AR & Juab & 0 & & 0 & 14 & 4 & 0 & 4 & 0 & 0 & 4 & 8 & 10 & 158 & 0 & 0 & 0 \\
\hline $\mathrm{J} 3$ & WS-GS & L.AR & Juab & 0 & & 0 & 12 & 0 & 0 & 0 & 0 & 0 & 6 & 6 & 10 & 164 & 0 & 0 & 4 \\
\hline J4 & WS-GS & L.AR & Juab & 0 & & 0 & 4 & 18 & 2 & 0 & 6 & 0 & 2 & 2 & 32 & 108 & 28 & 0 & 2 \\
\hline J5 & GS-WS & L.AR & Juab & 0 & & 0 & 8 & 14 & 0 & 0 & 0 & 0 & 14 & 8 & 16 & 128 & 14 & 0 & 0 \\
\hline $\mathrm{Sh} / \mathrm{Ju}$ & WS & L.AR & Shingle & 0 & & 0 & 6 & 2 & 0 & 0 & 0 & 0 & 8 & 4 & 40 & 142 & 0 & 0 & 0 \\
\hline UF1 & PS & M.AR & $\begin{array}{l}\text { Upper } \\
\text { Fillmore }\end{array}$ & 0 & & 0 & 0 & 10 & 0 & 0 & 0 & 0 & 40 & 6 & 16 & 78 & 0 & 0 & 52 \\
\hline WW1 & WS & M.AR & Wah Wah & 0 & & 0 & 4 & 0 & 0 & 0 & 0 & 0 & 8 & 2 & 4 & 178 & 0 & 4 & 0 \\
\hline WW2 & MS & M.AR & Wah Wah & 0 & & 0 & 0 & 0 & 0 & 0 & 0 & 4 & 2 & 4 & 16 & 176 & 0 & 0 & 0 \\
\hline
\end{tabular}


TABLE 1-Continued.

\begin{tabular}{|c|c|c|c|c|c|c|c|c|c|c|c|c|c|c|c|c|c|c|}
\hline Sample & Dunham & Age & Formation & Nuia & Unid.Alga & Brach. & Echino. & Gastro. & Biv. & Ostra. & Por. & Trilo. & Unid & Spar & Micrite & ?Carb. & Intra. & Pel. \\
\hline WW3 & WS/GS & M.AR & Wah Wah & 0 & 0 & 2 & 12 & 0 & 0 & 0 & 0 & 10 & 2 & 12 & 164 & 0 & 0 & 2 \\
\hline WW4 & FPC & M.AR & Wah Wah & 0 & 0 & 2 & 6 & 0 & 0 & 0 & 0 & 26 & 12 & 36 & 80 & 0 & 40 & 0 \\
\hline WW5 & GS & M.AR & Wah Wah & 0 & 2 & 2 & 34 & 0 & 0 & 0 & 0 & 34 & 14 & 32 & 42 & 0 & 38 & 4 \\
\hline WW6 & WS & M.AR & Wah Wah & 0 & 0 & 4 & 0 & 8 & 0 & 0 & 0 & 14 & 6 & 22 & 132 & 0 & 0 & 18 \\
\hline WW7 & FPC & M.AR & Wah Wah & 0 & 0 & 8 & 6 & 0 & 0 & 0 & 0 & 12 & 20 & 14 & 6 & 0 & 136 & 0 \\
\hline $\mathrm{K} 1$ & WS-PS & LLA & Kanosh & 0 & 0 & 6 & 0 & 0 & 0 & 6 & 0 & 4 & 2 & 44 & 132 & 0 & 0 & 8 \\
\hline $\mathrm{K} 2$ & WS & LLA & Kanosh & 0 & 0 & 2 & 0 & 12 & 4 & 0 & 0 & 4 & 4 & 24 & 154 & 0 & 0 & 0 \\
\hline K3 & WS-GS & LLA & Kanosh & 8 & 0 & 16 & 4 & 0 & 0 & 2 & 0 & 6 & 12 & 22 & 134 & 0 & 0 & 0 \\
\hline K4 & MS & LLA & Kanosh & 0 & 0 & 6 & 2 & 0 & 0 & 0 & 0 & 4 & 2 & 24 & 166 & 0 & 0 & 0 \\
\hline K5 & GS-WS & LLA & Kanosh & 0 & 0 & 10 & 4 & 2 & 0 & 14 & 0 & 26 & 8 & 64 & 64 & 0 & 0 & 14 \\
\hline
\end{tabular}

sample size for robust statistical analysis, the sampled beds were chosen because they are, in our experience, representative of a range of lithofacies. Additional sampling would help to improve the statistical robustness of our estimates and ultimately allow us to examine trends within individual lithofacies at higher resolution; however, we do not believe the further effort would alter the observed pattern at the broad scale under consideration here. Thin sections were prepared from beds characterized by good preservation of original fabric (i.e., absence of substantial fabric-destructive diagenesis). Note that although thin sections were examined from the Felix Member and Watts Bight Formation (Newfoundland), and lower Fillmore Formation (Utah), none of these slides figure in our analysis because of the poor quality of petrographic preservation. In no case were fossiliferous slides excluded from any time interval. On each slide, 200 points were counted and classified following the grain-solid method using a mechanical stage (e.g., Jaanusson, 1972; Flügel, 1982; Payne et al., 2006).

Although the point-counting method provides information about the importance of skeletons within individual carbonate facies, it is also important to consider the relative contributions of different facies to overall carbonate depositional packages as they changed through time (Sepkoski et al., 1991; Droser and Sheehan, 1997). To estimate changes in skeletal contributions at the section scale, we measured the contribution of each facies type to overall thickness in a Series 3 (Cambrian) to Lower Ordovician succession in Newfoundland and three Lower-Middle Ordovician sections in western Utah and eastern Nevada (Finnegan and Droser, 2005). Thicknesses for each facies were then multiplied by the average proportion of skeletal carbonates in thin sections from the facies under consideration, and these products were summed and divided by the total thickness to obtain a thicknessnormalized estimate of skeletal carbonate contribution at the section scale (e.g., Payne et al., 2006). For example, in a $10 \mathrm{~m}$ section, containing $8 \mathrm{~m}$ of facies A with a mean skeletal content of $5 \%$ and $2 \mathrm{~m}$ of facies B with mean skeletal content of $15 \%$, the estimate of mean skeletal content for the entire section would be:

$$
[(8.0 \times 0.05)+(2.0 \times 0.15)] \div 10.0=0.07
$$

Finally, to get a broader sense of changes in skeletal carbonate production across all of Laurentia, a meter-scale stratigraphic database of carbonate sections from various sites in Laurentia was compiled. We selected literature sources based on the detail of stratigraphic columns or presence of detailed written descriptions. Pure carbonate sections were first-order targets, but mixed carbonate-siliciclastic successions were used as long as carbonates comprised $\geq 50 \%$ of the section. We selected sections to provide a broad geographic coverage of the eastern, western, and southern margins of Laurentia and to encompass a diversity of shallow to deep subtidal depositional settings. We did not tabulate heavily dolomitized sections unless their fabrics were sufficiently preserved to determine original skeletal composition. The stratigraphic resolution of these data is lower than those available for Newfoundland and the Ibex area and we cannot provide direct estimates of proportional skeletal contribution for these sections, but this compilation allows us to place the local patterns evident in our field observations within a broader paleogeographic context.

We categorized each meter of carbonate in the selected sections according to the following coarse binning scheme: micrite, oolite, microbialite, or skeletal limestone (fossil packstones and grainstones, broadly equivalent to shell beds of $\mathrm{Li}$ and Droser [1997, 1999]). For our purposes, a section is defined as a single formation or member at a single locality. When available, multiple sections of the same formation were tabulated to observe variation within a single stratigraphic unit. We calculated the proportion of skeletal carbonate for 34 sections of Series 3 and Furongian Cambrian carbonates and 24 Ordovician sections.

Principal Components Analysis (PCA; Joliffe, 2002) was used to ordinate the stratigraphic sections according to the cumulative relative thicknesses of the above four compositional categories. While it is traditional to use ternary diagrams for point-count modal data, PCA allows us to quantitatively examine higher dimensional data, in this case the four genetic categories of carbonate sediment. The PAST package (Hammer et al., 2001) was used for analyses. Other commonly used multivariate ordination techniques such as Detrended Correspondence Analysis and Nonmetric Multidimensional Scaling give closely similar ordinations, which is not surprising given the small number of variables. For this reason, alternative ordinations are not presented.

Both our field sampling and literature compilation focused on carbonate and mixed carbonate-siliciclastic strata. Although carbonate skeletal material can also be preserved in siliciclastic rocks, it is difficult to establish a relationship between skeletal abundance and changes in the nature of carbonate production in these settings. Temporally, our sampling is limited to the Series 3 (Cambrian) to Late Ordovician interval. Despite the dramatic radiation of animal life during the Cambrian Explosion, shell-bed analyses of lower Cambrian sections suggest that carbonate skeletons were a relatively minor component of level-bottom carbonate production during this time ( $\mathrm{Li}$ and Droser, 1997). Relatively little work has been done to quantify the local or global influence of archaeocyathid reefs on carbonate sedimentation during the early Cambrian, but this is an interesting area for continuing study, as lower Cambrian carbonates may well be more skeleton rich than those deposited later in the period (e.g., James et al., 1989). Whatever impact archaeocyathid and other sponge-rich reefs had as a skeletal sink for carbonate, it was relatively short-lived, as metazoan reefs virtually disappeared at the end of the early Cambrian (Zhuravlev and Wood 1996) and did not reappear in abundance until Middle Ordovician time (e.g., Rowland and Shapiro, 2002).

\section{RESULTS}

\section{Point Counts}

Figure 3 shows the percentage of skeletal material identified in point counts of the Cambrian and Ordovician carbonates and Table 1 shows the identified points. In Cambrian samples, skeletal material, on 
average, accounted for $\sim 8 \%$ of points counted. Fossil content ranges up to $23 \%$, but the (weak) mode is $0 \%$. In total, 12 grainstone thin sections (excluding oolites) were analyzed, and these contained the highest average skeletal content $(\sim 10 \%)$. Lower Ibexian (Tremadocian) samples are similar to those of Cambrian age, with skeletal material accounting for an average $4 \%$ of points counted, but late Ibexian and Whiterockian samples are distinctly different, with skeletal material accounting for $18 \%$ and $16 \%$ of total points, respectively. The maximum is $42 \%$, which is near the observed maximum potential for shell beds of $\sim 50 \%$ (Payne et al., 2006). Both micrite and microbial microfacies occur in abundance in many Cambrian and Ordovician slides; the notable difference between Cambrian and Ordovician thin sections is the contribution of fossil material to total points counted (see Table 1).

Similar facies in the Cambrian and post-Tremadocian Ordovician sections also show different proportional abundances of skeletal material. For instance, Cambrian grainstones contain at most $23 \%$ fossil material, whereas mid-Floian grainstones contain $\leq 42 \%$. Similarly, Cambrian flat-pebble conglomerates, formed by the local redistribution of carbonate clasts during storms (e.g., Sepkoski, 1982) contain at most $9 \%$ fossil material, whereas fossil material accounts for $23 \%$ of points counted in both Ordovician flat-pebble conglomerates examined. Flat-pebble conglomerates were sampled in thin section but were not separated into a distinct category when calculating the volume of carbonate for Cambrian sections because these units are often lenticular and commonly recessive in Newfoundland. Sample sizes were largely selected to capture the variation within facies and to reflect local stratigraphy, and clear outliers were excluded (e.g., heavily dolomitized samples). In no case, however, did we exclude unusually fossiliferous Cambrian rocks.

In the Ibex area, at least, the major shift in the proportional contribution of skeletal materials thus occurs in samples deposited between the Tremadocian (early Ibexian) and the mid-Floian (late Ibexian-early Whiterockian) (Fig. 3); no post-Tremadocian samples contain $<5 \%$ skeletal material, a minimum that is higher than median values for both later Cambrian and Tremadocian samples. Correlative formations to the west in central Nevada show a similar pattern of low skeletal concentration at the outcrop level in the Tremadocian and a mid-Floian-Dapingian increase, though skeletal concentrations are

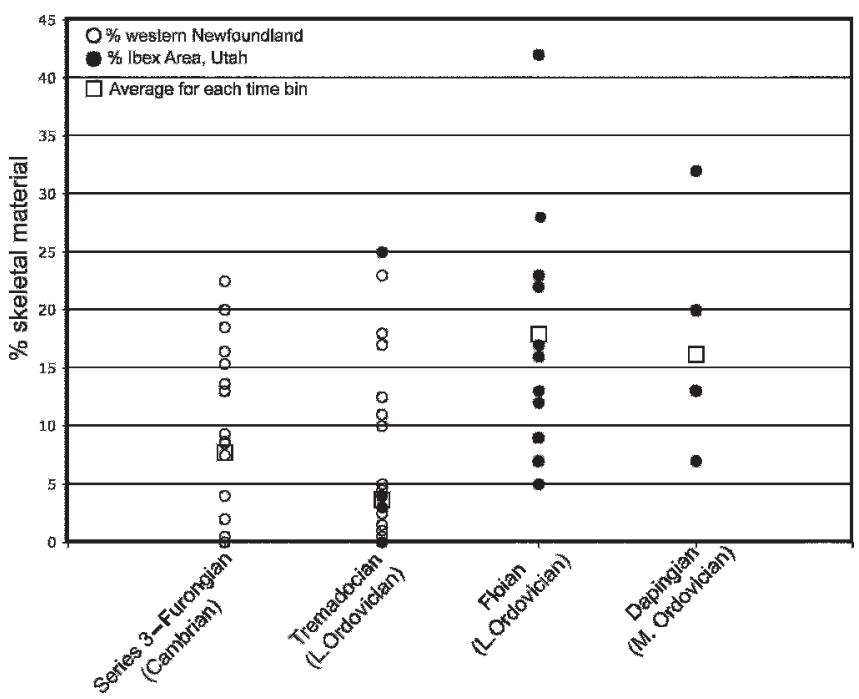

FIGURE 3-Cambro-Ordovician thin section skeletal abundances. Diagram showing percent bioclastic material based on point counts of thin sections (200 points/ slide). Series 3-Furongian (Cambrian) and some Tremadocian data are from thin sections of samples from western Newfoundland. Tremadocian, late Floian, and Dapingian data were generated from thin sections of carbonates of Lower and Middle Ordovician strata from Utah and Nevada. generally lower in these deeper-water units (SF, unpublished observations, 2007).

In addition to secular change in the abundance of fossil material, there are differences in the taxonomic composition of carbonate skeletons from pre- and post-Tremadoc samples (Table 1). Similar changes were documented at Ibex and in other areas of the western United States by Li and Droser (1997, 1999). Fossil material preserved in Newfoundland Cambrian thin sections is dominated by trilobite and echinoderm debris. Uncommon trilobite-rich beds occur primarily in deeper-water facies of the March Point Formation (MF17, MF38; Table 1). Echinoderms show a different distribution, with plates preserved most abundantly in the interstices of microbial mounds, particularly thrombolites (CMCC1, CM28MI3) and in associated shallow-water grainstones (MWU6, CM15). Trilobites and echinoderms generally dominate the skeletal carbonate signal in early Ibexian (Tremadocian) samples from the Ibex area, but post-Tremadocian fossil material from Ibex Area is more diverse. Trilobites and echinoderms are still significant components (UF1, WW5), but calcitic brachiopods are also common (L.NM1). Less common fossil grains include ostracodes, mollusks, and sponges. Outcrop observations suggest a similar pattern of skeletal diversification in Ordovician carbonates from Newfoundland (SP, unpublished observations, 2007).

\section{Measured Sections}

When generalized to the section scale, these results point to a substantial increase in the skeletal contribution to carbonates between the Furongian (Cambrian) and the Middle Ordovician. In the Cambrian Port au Port Group of western Newfoundland, carbonate mudstones and oolites make up the bulk of the section (Fig. 4) and in thin section contain very little skeletal material $(1 \%$ and $4 \%$, respectively). As expected, grainstones contain the most recorded skeletal material in thin section $(\sim 10 \%)$. As a proportion of total carbonate production, skeletal carbonate makes up 2.8\% of Cambrian units examined (Fig. 5), corroborating qualitative observations that most later Cambrian carbonates do not have a demonstrably skeletal origin. A wide range of environments is preserved in the Port au Port and St. George groups of western Newfoundland. Subtidal and peritidal settings are present in the Cambrian March Point and Petit Jardin formations and facies become increasingly restricted in the Lower Ordovician (Fig. 4).

Although they preserve a range of environments broadly similar to those in the Port au Port, late Floian (late Ibexian and early Whiterockian) sections in western Utah show a much higher contribution of skeletal material to total carbonate production. The most abundant carbonate lithofacies in these sections is mudstonewackestone (Fig. 4), which contains on average 13\% fossil material in thin section, much higher than skeletal abundances in upper Cambrian mudstones. The next most abundant facies, which makes up only $10 \%$ of total carbonates, is grainstone. Again, these Ordovician grainstones are far richer in skeletal debris than their Cambrian counterparts, containing an average of $32 \%$ carbonate fossil material in thin section. In total, the Thomas Range, Ibex, and Shingle Pass areas show that skeletons make up $15 \%$ and $14 \%$ of total carbonate volume, respectively, when normalized for abundances of different lithofacies (Fig. 5). Although the Ibex section displays some environmental variation, the range of variation is relatively constrained and does not appear to influence temporal changes in skeletal abundance (Fig. 3). For example, the House Limestone, Wah Wah Limestone, and Juab Limestone all show similar parasequence development indicative of shallow subtidal deposition, but the bioclastic content of the latter two units is substantially higher than the former.

Plotting the proportion of each stratigraphic unit logged as bioclastic limestone against age (Fig. 6) demonstrates that, despite differences in depositional environment and basin evolution, these two areas show 
A

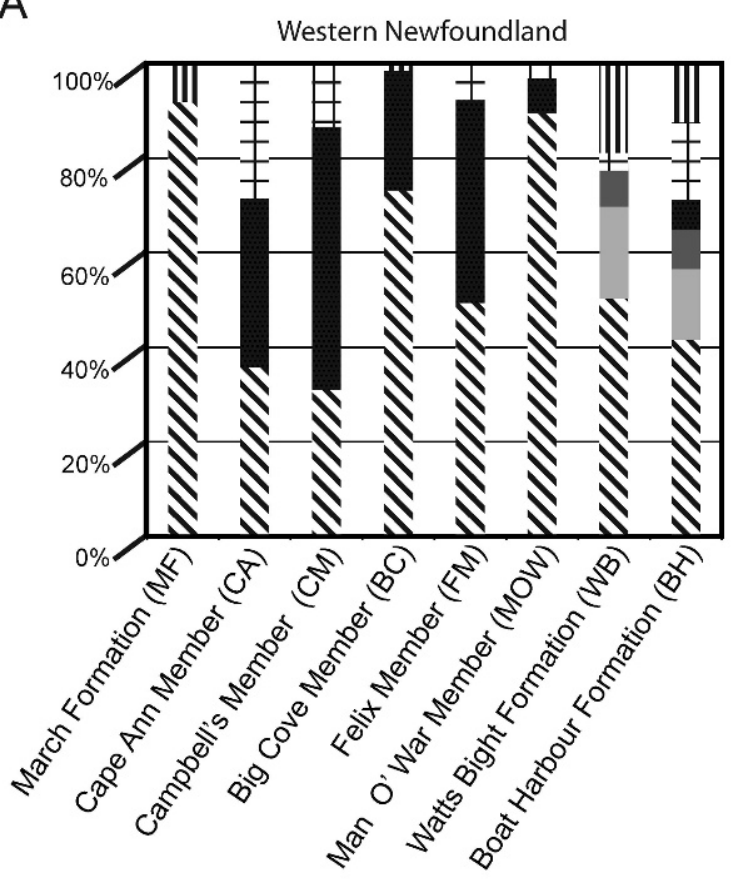

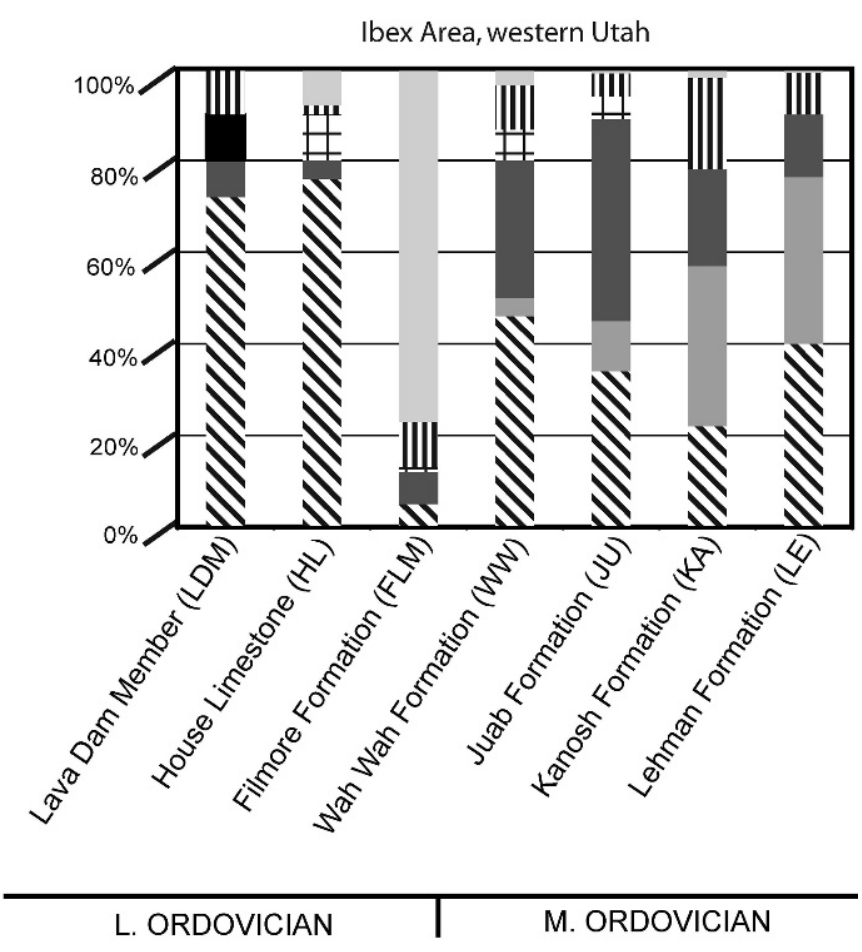

B

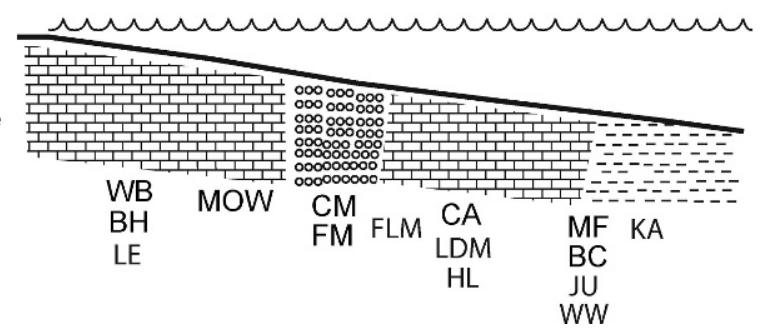

FIGURE 4-Proportion of facies in Cambro-Ordovician strata. Diagrams showing proportion of lithofacies through time at each locality and general environmental distribution of stratigraphic units. A) Bar graphs showing proportion of lithofacies observed in outcrop from western Newfoundland (Series 3 and Furongian) and the Ibex Area, Utah (Lower and Middle Ordovician). B) Environmental transect showing approximate locations of depositional units in A.

broadly similar trends in bioclastic production through time. The proportional representation of bioclastic limestones is generally higher in the Ibex area, reflecting both genuine and methodological differences, but both sections exhibit comparatively low values in the Furongian, intermediate values in the Tremadocian (early Lower Ordovician), and high values by the late Floian (latest Lower Ordovician) time (Fig. 6).

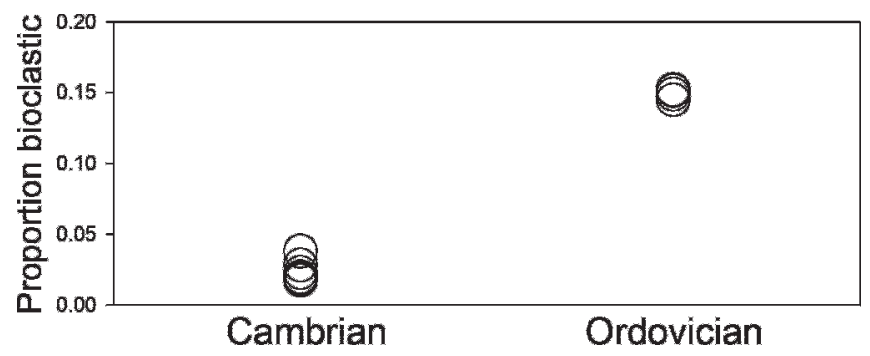

FIGURE 5-Abundance of skeletal material as a fraction of lithofacies volume for the Cambrian of Newfoundland and Ordovician of the Ibex Area, Utah (see text for further explanation).

\section{Literature Compilation}

To test whether the trend apparent in the two regions studied is representative of the broader pattern, we compiled measured sections of Cambrian and Ordovician strata throughout North America. As we did with measured sections from the two regions (Fig. 6), we calculated proportions of skeletal carbonates by tabulating the meters of skeletal limestone, as reported in published measured sections and dividing by the total thickness of the section.

At the continental scale, skeletal grainstones account for $8 \%$ of all meters of carbonates binned in the 34 Series 3 and Furongian Cambrian sections analyzed. Proportional abundance of meters of fossiliferous rock ranges among sections from $0 \%$ to $72 \%$, with a median for individual sections of $2.8 \%$. Lower Ordovician carbonates are similar to Cambrian carbonates in containing on average $\sim 10 \%$ carbonate skeletal meters, with a range of $0 \%-54 \%$ and a median of $1.5 \%$. Middle and Upper Ordovician carbonates show a significant increase in skeletal material in outcrop; skeletal limestones account for $60 \%$ of total measured meters of carbonates. It is striking that the minimum value for any individual Middle or Upper Ordovician unit is $12 \%$, with a median of $53 \%$.

A Principal Components Analysis (PCA) of carbonate composition for all sections in the dataset illustrates the general trend. Series $3-$ 

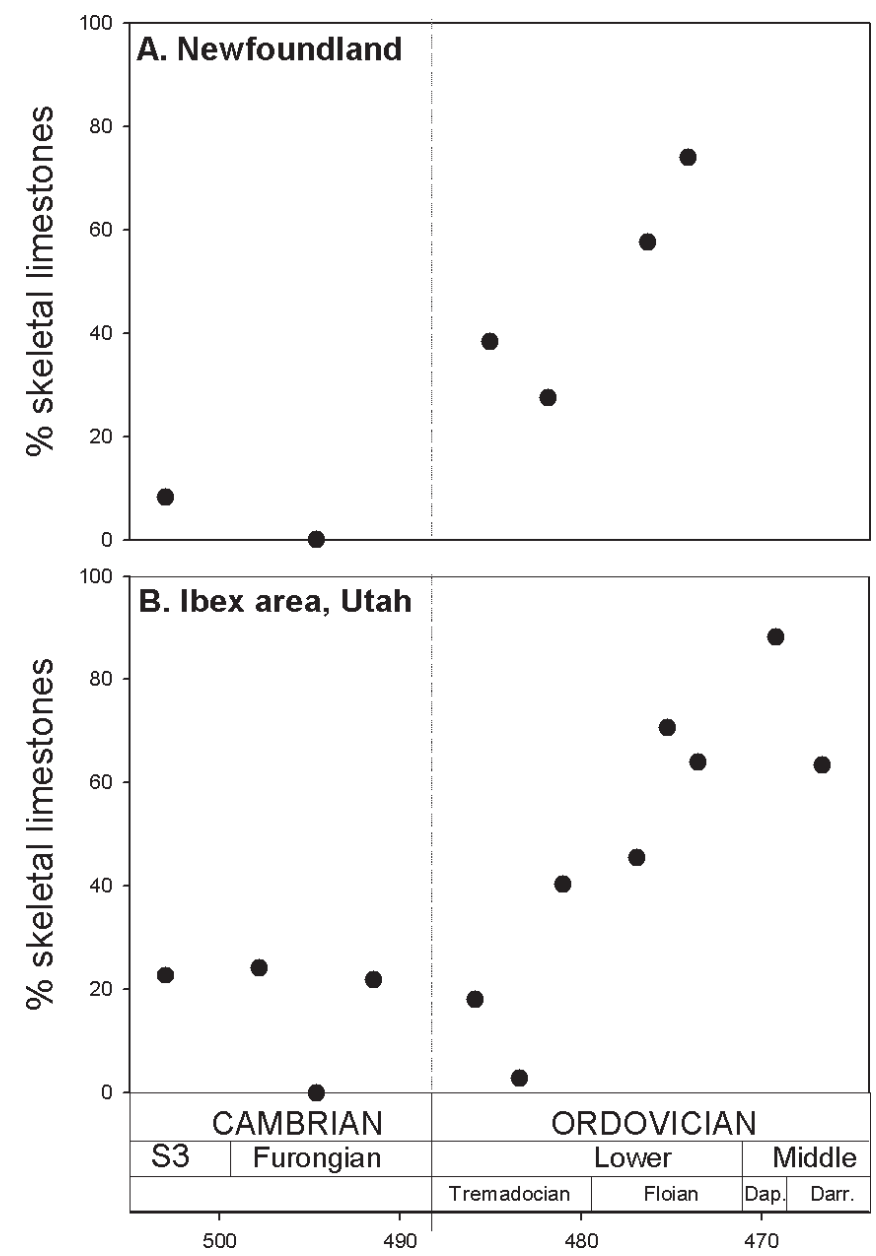

FIGURE 6-Proportions of stratigraphic units (formations or members) logged as skeletal limestone (fossil wackestones, packstones, or grainstones), plotted against age in measured sections from A) Newfoundland (S. Pruss, field notes, 2005-2006) and B) Utah (compiled from S. Finnegan field notes, 2000-2005, and from Hintze, 1973); S3 $=$ Series $3 ;$ Dap. $=$ Dapingian; Dar. $=$ Darriwilian

Furongian Cambrian sections and Middle to Upper Ordovician sections comprise essentially non-overlapping groupings, with Lower Ordovician sections spanning the full range (Fig. 7). Skeleton-rich limestones formed in later Cambrian seaways, but Cambrian sections are dominated lithologically by micrites, oolites, and microbialites. In contrast, post-Tremadocian Ordovician sections are dominated by skeletal limestones.

\section{DISCUSSION}

The late Cambrian-Early Ordovician interval stands out as distinctive against the broad background of Phanerozoic marine evolution. Skeletons, largely trilobite and echinoderm remains, make only a limited contribution to limestones of this age, with abundant ooids, microbialites, and micrites suggesting a carbonate factory dominated by physical and microbial processes. In particular, reefforming metazoans were scarce for 40 myr following archaeocyathid extinction (Rowland and Shapiro, 2002), radiating again in the Middle Ordovician.

Following this interval, a sharp global increase in the generic diversity of carbonate-secreting metazoans (Sepkoski, 2002; Webby et al., 2004; Peters, 2005a) (Fig. 8) and an increase in the depth and complexity of bioturbation suggests rapid diversification and ecological transformation (Droser et al., 1996; Miller and Foote, 1996; Adrain et al., 1998; Webby et al., 2004). That the diversity and abundance of well-skeletonized

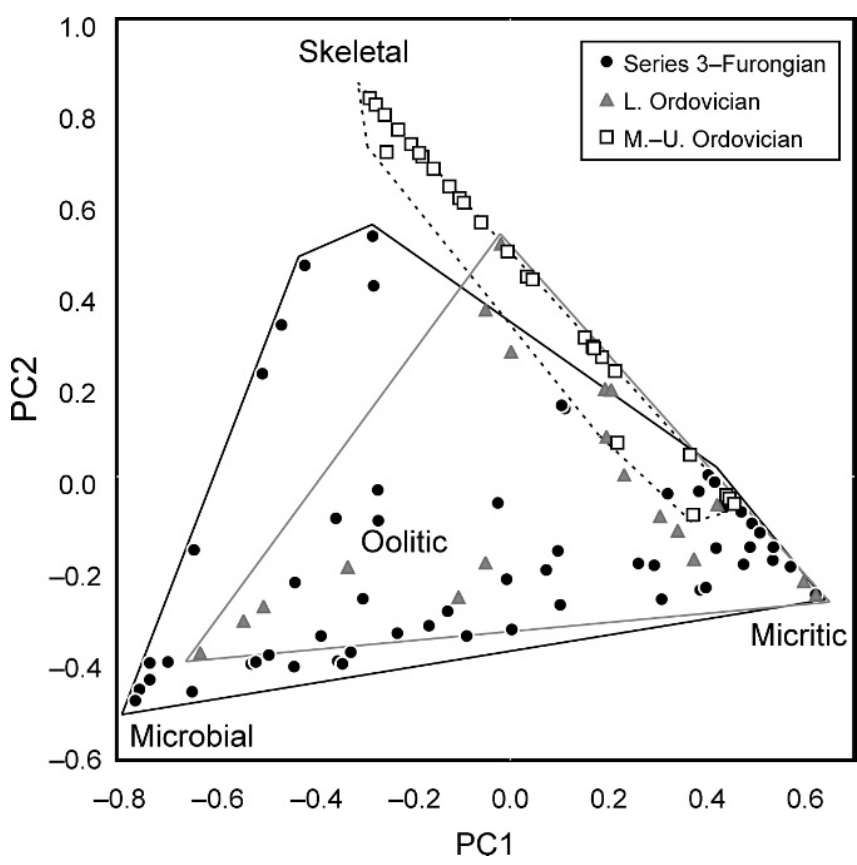

FIGURE 7-Principal Components Analysis of all unique formation-memberlocality combinations. Four independent (but normalized) variables are shown: \% Microbial carbonates, \% Oolites, \% Skeletal carbonates, and \% Micritic carbonates. Labels show where pure micrite, skeletal limestone, oolite, and microbial carbonate would occur (see Supplementary Data ${ }^{1}$ for sources used).

organisms increased in the Ordovician is a long-standing observation; however, quantification of the patterns presented here permits a morefocused evaluation of competing explanatory hypotheses.

Our data permit a test of the trends reported by Li and Droser (1997, 1999) for the Ibex area of Utah. The three data sets assembled here confirm a marked increase in shell-bed abundance in the Ibex region; furthermore, our data (despite differing taphonomic biases) reveal that the proportional abundance of identifiable skeletons in carbonate rocks increased across facies and, indeed, throughout Laurentia. Thus, all observations point toward the same conclusion (see Supplementary Data $^{1}$; Fig. 7). For comparison, skeletons can account for $90 \%$ of total

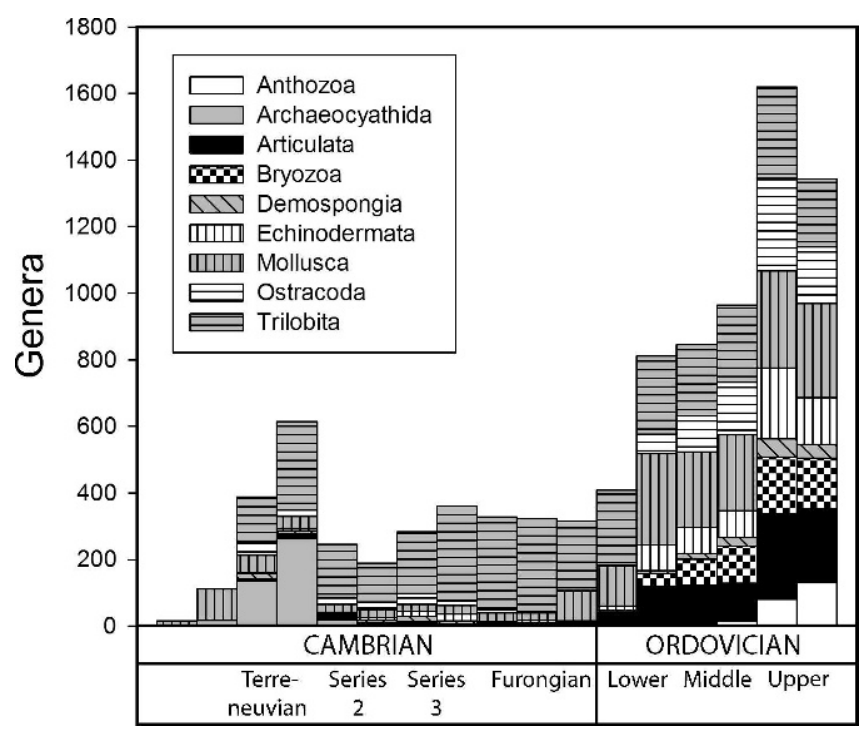

FIGURE 8-Generic diversity of calcifying animal groups from the Cambrian into the Ordovician (Peters [2005a] database, using Sepkoski's [2002] data).

${ }^{1}$ www.paleo.ku.edu/palaios 
carbonate production in some modern settings (e.g., Harney, 2003), although it is clear that estimates of modern bioclastic carbonate cannot be compared directly to the diagenetically altered samples from the Paleozoic described in this study. The skeletal contribution to Cambrian carbonates was high locally, but, on average, skeletal material accounted for a comparatively small proportion of total carbonate production on later Cambrian shelves and platforms. Several of the units examined contained no significant skeletal carbonate contribution, including some in western Newfoundland. Lower Ordovician carbonates also show a relatively small contribution of fossil material to total carbonate production; like the Cambrian sections analyzed, many units contained no fossil material, with an average of $8 \%$ of all meters analyzed containing abundant fossil debris.

The distribution of skeletal content in Middle and Upper Ordovician carbonates is strikingly different. Although fossil-rich limestones make up a relatively small proportion of a few individual Middle and Upper Ordovician carbonate sections (Platteville Group, 122 m, 12\% fossiliferous limestones; Fanton, 2004), the general trend shows a dramatic increase in the total amount of skeletal contribution to carbonates. In rare instances, skeletal materials made up the vast majority of limestones analyzed: Hull Formation 1, $45 \mathrm{~m}, 90 \%$ fossiliferous limestones (Kiernan, 1999) and Galena 2, $130 \mathrm{~m}, 100 \%$ fossiliferous limestones (Fanton, 2004). We note that the successions we examined commonly contain trace fossils and that shales sampled preserve abundant invertebrate cuticle in Newfoundland (SP, unpublished observations, 2007). For this reason, we doubt that the patterns reported here derive principally from low oxygen or some other inhibitor of metazoans on late Cambrian shelves and platforms (Peters, 2007), as animals appear to have been abundant; only carbonate skeletons are scarce. In this context it is also notable that the average degree of bioturbation in Basin and Range carbonates is essentially unchanged between the Series 3 Cambrian and the Middle Ordovician (Droser and Bottjer 1989), despite a substantial increase in skeletal content over the same interval ( $\mathrm{Li}$ and Droser 1996, 1999; this study). Put another way, we do not argue that organisms such as mollusks and cnidarians were rare in Late Cambrian oceans, but rather that these taxa contributed little to the marine carbonate cycle.

Our compilation is limited to shallow-to-deep, subtidal, pure carbonate and mixed carbonate-siliciclastic depositional systems; thus, regional environmental variation is only coarsely controlled. It is likely that the signal we see is influenced both by a secular trend in skeletal biomass and by changes in environmental representation through time; in carbonate settings, these will not be independent of skeletal evolution. This study emphasizes, however, that the Cambro-Ordovician is one of relatively few Phanerozoic intervals that shows rapid and significant increases in diversity even after accounting for variation in outcrop area (Peters, 2005b); further work on the macrostratigraphic character of the Cambrian-Ordovician transition (e.g., Peters, 2006) will be necessary to untangle temporal and environmental effects completely.

While the Ordovician radiation of skeletal taxa has long been recognized (e.g., Sepkoski, 1978; Webby et al., 2004), the drivers of this event remain poorly understood (Botting and Muir, 2008). A variety of explanations ranging from purely biological (Peterson, 2005) to purely physical (Patzkowsky and Holland, 1993; Miller and Mao, 1995) have been proposed, and no consensus has emerged to date. One key insight is that the Ordovician radiation extends across clades; heavily calcified skeletons came to characterize rhynchonelliform brachiopods, echinoderms, mollusks, bryozoans, sponges, and corals alike, not to mention the diversification of skeleton-forming algae (Fig. 7). Many of these organisms were sessile filter feeders, but motile grazers, carnivores, and primary producers were represented as well. Thus, clade- or functionspecific explanations cannot account for the observed pattern of diversification. The second key observation is that a long interval of time ( $>40$ myr) separates the initial Cambrian appearance of many skeletal taxa from their subsequent Ordovician diversification (e.g., Rowland and Shapiro, 2002). What might explain this apparent delay? We suggest evolving seawater carbonate chemistry over this interval may provide a key to understanding the apparent delayed timing of the Ordovician radiation.

In all cases, skeletal biomineralization requires energetic input by individual organisms, and this energetic input (or cost) is a strong function of the availability of the chemical constituents required to assemble a skeleton $\left(\mathrm{Ca}^{2+}\right.$ and $\mathrm{CO}_{3}{ }^{2-}$ in this case, along with associated organic molecules). Given the abundance and diversity of skeleton-forming organisms, the benefits gained by biomineralization must be worth the energy expended - energy that might otherwise be used for reproduction (e.g., Knoll, 2003). This cost-benefit tradeoff must have existed since the earliest biomineralizers evolved near the Proterozoic-Cambrian boundary, providing a useful framework for examining times of low skeletal abundance: were the costs of skeletonization too high or the benefits too low? If so, which factor most strongly influenced the Ordovician skeletal revolution: a ramping up of predation pressure (increasing the benefit) or a change in ocean chemistry (decreasing the cost)?

For many marine invertebrates, the cost associated with producing a skeleton of $\mathrm{CaCO}_{3}$ is a function of the thermodynamic state of saturation in the surrounding fluid, $\Omega=\left[\mathrm{Ca}^{2+}\right] \cdot\left[\mathrm{CO}_{3}{ }^{2-}\right] \cdot \mathrm{k}_{\mathrm{sp}}{ }^{-1}$, where $\mathrm{k}_{\mathrm{sp}}$ is the empirically derived solubility constant for a particular $\mathrm{CaCO}_{3}$ polymorph (e.g., calcite or aragonite). Values of $\Omega>1$ describe geochemical systems where $\mathrm{CaCO}_{3}$ tends to precipitate, whereas solutions of $\Omega<1$ are corrosive to $\mathrm{CaCO}_{3}$. The rate at which $\mathrm{CaCO}_{3}$ precipitates or dissolves depends directly on the magnitude of deviation from $\Omega=1$ (Morse et al., 2007). For organisms that must precipitate a skeleton at a given rate, living in seawater of sufficient $\Omega$ is imperative. A large number of studies have examined the effects of $\Omega$ on calcification rate for a diverse collection of extant marine organisms: e.g., hermatypic and ahermatypic corals, foraminifera, echinoderms, coralline algae, and both mesocosm and natural coral-reef communities. In general, as $\Omega$ drops, so does calcification rate, dramatically so for many taxa (Kleypas et al., 1999; Pörtner, 2001; Feeley et al., 2004; Pörtner et al., 2004; Langdon and Atkinson, 2005, and references therein).

Limited data on fluid inclusions in evaporite minerals provide conflicting time series trends for $\left[\mathrm{Ca}^{2+}\right]$ increase in earliest Cambrian oceans (Brennan et al., 2004; Petrychenko et al., 2005). Model results do not reveal any strong variation in calcium-ion abundance through the later Cambrian-Middle Ordovician interval of interest (e.g., Demicco et al., 2005). Regardless of changing seawater chemistry, when $\left[\mathrm{Ca}^{2+}\right]$ far exceeds $\left[\mathrm{CO}_{3}{ }^{2-}\right], \mathrm{Ca}^{2+}$ may saturate calcium-binding sites on organic templates long before carbonate-binding sites fill, resulting in strong $\left[\mathrm{CO}_{3}{ }^{2-}\right]$ control of precipitation kinetics (Obst et al., 2009). For these reasons, and because $\mathrm{Ca}^{2+}$ is far more abundant than $\mathrm{CO}_{3}{ }^{2-}$ in seawater, likely for the past 540 myr (e.g., Horita et al. 2002) and perhaps much longer, the distribution of $\Omega$ values in later Cambrian and Ordovician seawater must have been controlled largely by changes in carbonate-ion abundances due to the addition or removal of $\mathrm{CO}_{2}$.

Seawater today is characterized by strong gradients in $\Omega$ due, in large part, to the biological pump and the oxygenic production-aerobic respiration of organic carbon (Higgins et al., 2009). The biological pump removes $\mathrm{CO}_{2}$ (a weak acid) from surface seawater and adds it at depth (e.g., Broecker and Peng 1982; Hotinski et al., 2004). Correspondingly, $\Omega$ is strongly supersaturated in surface seawater $(\Omega$ = 4-6 for calcite; Li et al., 1969) and tends to be undersaturated at depth in the water column and sedimentary pore fluids. Building on the observation, however, that all anaerobic carbon metabolic pathways either produce or consume alkalinity in addition to $\mathrm{CO}_{2}$, more recent work (Fischer et al., 2007; Higgins et al., 2009) has revealed that in past times when anaerobic cycling of organic carbon was more importanti.e., in times of ocean anoxia - the gradients of $\Omega$ in seawater would have been reduced. While the average seawater $\Omega$ integrated globally likely changed little under anaerobic conditions, and therefore overall 
rates of carbonate production remained the same, this weakening of $\Omega$ gradients would have meant the loss of the extremes in saturation, including the strongly oversaturated surface seawater critical for the rapid production of invertebrate skeletons. As long as gradients in $\Omega$ remained reduced, the energetic costs associated with producing a skeleton of $\mathrm{CaCO}_{3}$ might have been prohibitively high, especially for organisms with a limited physiological ability to pump ions selectively across membranes.

On the basis of widespread black shales and low C:S ratio, widespread dysoxia and local anoxia have long been inferred for subsurface water masses of Series 3 and Furongian Cambrian oceans (e.g., Berry and Wilde, 1978; Raiswell and Berner, 1986; Zhuravlev and Wood, 1996; Hallam, 1998; Gaines et al., 2005; Hough et al., 2006; Hurtgen et al., 2009). Recent geochemical research supports earlier hypotheses and indicates that at times subsurface anoxia may have been global (Gill et al. 2007). In addition, oxygen-isotope ratios in conodont phosphate support the hypothesis that later Cambrian-Early Ordovician oceans were warm, with global cooling coincident with the main pulse of the Ordovician radiation (Trotter et al., 2008). The prevalence of warm temperatures during the later Cambrian-Early Ordovician may have contributed to low levels of dissolved oxygen in subsurface seawater via the effect of temperature on the Henry's Law constant (Rowland and Shapiro, 2002). The consequent development of subsurface anoxia would then have reduced oversaturation with respect to $\mathrm{CaCO}_{3}$ minerals in surface waters. If so, increased ventilation of Ordovician oceans, driven by global cooling (e.g., Trotter et al., 2008), would have increased the oversaturation of surface seawater with respect to calcite and aragonite, thereby reducing the physiological cost of skeleton construction.

In this view, then, the timing of the Ordovician radiation might be understood in the context of increasing availability of carbonate ion $(>\Omega)$ in surface seawater due to the effects of long-term cooling of climate and waning ocean-basin anoxia. It is important to note that taxa with carbonate skeletons are not the only organisms that diversified during Ordovician time. For example, siliceous sponges, often associated with microbial mounds, diversified in the Early Ordovician (Brunton and Dixon, 1994; Carrera and Rigby, 2004), and trace fossils, indicators of soft-bodied diversity, show an increase in diversity during the Ordovician radiation (Mángano and Droser, 2004). The overall depth and extent of bioturbation also increased, albeit not until the Late Ordovician (e.g., Droser and Bottjer, 1989). Thus, it is clear that the Ordovician radiation cannot be divorced from the complex interactions of an evolving ecology. Nonetheless, emerging geochemical data suggest that environmental change might well have facilitated the evolution of heavily calcified skeletons across diverse clades of marine organisms. The notable increase in carbonate skeletal abundance is an important, even defining, aspect of this event.

Our focus on skeletal chemistry does not by itself rule out hypotheses such as bolide facilitation of Ordovician radiation (Schmitz et al., 2008), although it highlights a specific pattern that such hypotheses must be able to explain. Nor does it rule out bottom-up proposals that link animal radiation to changing patterns of primary production. Indeed, deep-ocean ventilation might well have facilitated changes in primary production of the kind that Servais et al. $(2008,2009)$ called upon to explain Ordovician animal evolution. Finally, decreasing metabolic cost of skeletonization does not rule out increasing benefit associated with enhanced predator pressure; the two hypotheses are not mutually exclusive. A focus on skeleton precipitation does, however, suggest that an additional class of hypothesis must be taken seriouslyone based on the changing carbonate chemistry of Cambro-Ordovician oceans. Understanding the several intervals of Phanerozoic time when skeletal abundance appears to have been low may ultimately reveal the complexity and bidirectionality of links between the carbonate cycle and evolution in the oceans.

\section{CONCLUSIONS}

Calcifying organisms regulate and respond to environmental perturbations in the carbonate system as a whole. Previous studies examined the effect that the early Cambrian emergence of carbonate skeletons exerted on shifting the locus and the mechanisms of marine carbonate production (Zeebe and Westbroek, 2003; Ridgwell and Zeebe, 2005). The results presented here, however, suggest that this shift did not occur until later in the Ordovician. Late Cambrian and earliest Ordovician carbonate deposition remained under the dominant influence of abiotic or microbially mediated precipitation processes. Despite the appearance of calcareous organisms near the Proterozoic-Cambrian boundary, the development of a quantitatively important skeletal sink for carbonate was not established until Middle Ordovician time.

\section{ACKNOWLEDGMENTS}

We thank the Agouron Institute (postdoctoral fellowship to SP) and NSF Grant DES 0420592 (AHK) for partial funding of this research and R. Bambach, A. Breus, A. Bush, M. Droser, J. Higgins, P. Hoffman, C. Marshall, A. Mushegian, J. Payne, J. Ross, and D. Schmandt for helpful conversations and field and laboratory assistance. We gratefully acknowledge the Smith College Department of Geosciences for assistance with thin-section preparation. Steve Holland, Shanan Peters, Steve Rowland, Steven Stanley, and an anonymous reviewer provided constructive reviews of the manuscript.

\section{REFERENCES}

Adrain, J.M., Fortey, R.A., and Westrop, S.R., 1998, Post-Cambrian trilobite diversity and evolutionary faunas: Science, v. 280, p. 1922-1925.

Bengston, S., and Conway Morris, S., 1992, Early radiation of biomineralizing phyla, in Lipps, J.H., and Signor, P.W., eds., Origin and Early Evolution of the Metazoa: Plenum, New York, p. 447-481.

Berry, W.B.N., and Wilde, P., 1978, Progressive ventilation of the oceans: An explanation for the distribution of the lower Paleozoic black shales: American Journal of Science, v. 278, p. 257-275.

Botting, J.R., and Muir, L.A., 2008, Unraveling causal components of the Ordovician Radiation: The Builth Inlier (central Wales) as a case study: Lethaia, V. 41, p. 111-125.

Boyer, D.L., and Droser, M.L., 2003, Shell beds of the Kanosh and Lehman Formations of western Utah: Paleoecological and paleoenvironmental interpretations: Brigham Young University Geology Studies, v. 47, p. 1-15.

Brennan, S.T., Lowenstein, T.K., and Horita, J., 2004, Seawater chemistry and the advent of biocalcification: Geology, v. 32, p. 473-476.

Brett, C.E., Mclaughlin, P.I., Cornell, S.R., and Baird, G.C., 2004, Comparative sequence stratigraphy of two classic Upper Ordovician successions, Trenton Shelf (New York-Ontario) and Lexington platform (Kentucky-Ohio): Implications for eustasy and local tectonism in eastern Laurentia: Palaeogeography, Palaeoclimatology, Palaeoecology, v. 210, p. 295-329.

Broecker, W.S., And Peng, T.-H., 1982, Tracers in the Sea: Eldigio Press, Lamont Doherty Geological Observatory, Palisades, 690 p.

Brunton, F.R., and Dixon, O.A., 1994, Siliceous sponge-microbe biotic associations and their recurrence through the Phanerozoic as reef mound constructors: PALAIOS, v. 9, p. 370-87.

Carrera, M.G., and Rigby, J.K., 2004, Sponges, in Webby, B.D., Paris, F., Droser, M.L., and Percival, I.G., eds., The Great Ordovician Biodiversification Event: Columbia University Press, New York, p. 102-118.

Chow, N., and James, N.P., 1987, Cambrian grand cycles: A northern Appalachian perspective: Geological Society of America Bulletin, v. 98, p. 418-429.

Cowan, C.A., and James, N.P., 1993, The interactions of sea-level change, terrigenous-sediment influx, and carbonate productivity as controls on Upper Cambrian Grand Cycles of western Newfoundland: Geological Society of America Bulletin, v. 105, p. 1576-1590

Demicco, R.V., Lowenstein, T.K., Hardie, L.A., and Spencer, R.J., 2005, Model of seawater composition for the Phanerozoic: Geology, v. 33, p. 877-880.

Droser, M.L., and BotTuer, D.J., 1989, Ordovician increase in extent and depth of bioturbation: Implications for understanding early Paleozoic ecospace utilization: Geology, v. 17, p. 850-852.

Droser, M.L., and Sheehan, P.M., 1995, Paleoecology of the Ordovician radiation and the Late Ordovician extinction event, in Cooper, J., ed., Ordovician of the 
Great Basin: Field Trip Guidebook volume for the 7th International Symposium of the Ordovician Systems: Pacific Section SEPM, Fullerton, p. 64-106.

Droser, M.L., and Sheehan, P.M., 1997, Palaeoecology of the Ordovician radiation: Resolution of large-scale patterns with individual clade histories, palaeogeography and environments: Géobios, Mémoire Special, v. 20, p. 221-229.

Droser, M.L., Fortey, R.A., and Li, X., 1996, The Ordovician radiation: American Scientist, v. 84 , p. $122-131$.

EMERSON, N. R., 2002, Sedimentology, sequence stratigraphy, and brachiopod biostratigraphy of the Ordovician (Mohawkian) Decorah Formation, Midcontinent, U.S.: Unpublished Ph.D. thesis, University of Wisconsin at Madison, 516 p.

FANTON, K., 2004, Sm-Nd and C-isotope chemostratigraphy of Ordovician epeiric carbonates, midcontinent of North America: Unpublished Ph.D. Thesis, University of Saskatchewan, Saskatoon, $152 \mathrm{p}$.

Feeley, R.A., Sabine, C.L., Lee, K., Berelson, W., Kleypas, J., Fabry, V., and Millero, F.J., 2004, Impact of anthropogenic $\mathrm{CO}_{2}$ on the $\mathrm{CaCO}_{3}$ system in the oceans: Science, v. 305, p. 362-366.

Finnegan, S., and Droser, M.L., 2005, Relative and absolute abundance of trilobites and rhynchonelliform brachiopods across the Lower/Middle Ordovician boundary, eastern Basin and Range: Paleobiology, v. 31, p. 480-502.

Fischer, W.W., Higgins, J.A., and Pruss, S.B., 2007, Delayed biotic recovery from the Permian-Triassic extinction may have been influenced by a redox-driven reorganization of the marine carbonate system, Geological Society of America Abstracts with Programs, p. 420.

FlÜGEL, E., 1982, Microfacies analysis of limestones: Springer, New York, 633 p.

Gaines, R.R., Kennedy, M.J., and Droser, M.L., 2005, A new hypothesis for organic preservation of Burgess Shale taxa in the Middle Cambrian Wheeler Formation, House Range, Utah: Palaeogeography Palaeoclimatology Palaeoecology, v. 220, p. 193-205.

Gill, B.C., Lyons, T.W., and Saltzman, M.R., 2007, Parallel, high-resolution carbon and sulfur isotope records of the evolving Paleozoic marine sulfur reservoir: Palaeogeography, Palaeoclimatology, Palaeoecology, v. 256, p. 156-173.

GinsburG, R.N., 1982, Actualistic depositional models for the Great American Bank (Cambro-Ordovician), in 11th International Congress on Sedimentology, Abstracts, 22-27 August 1982, Hamilton, Ontario, Canada: International Association of Sedimentologists, p. 114.

Grotzinger, J.P., Watters, W.A., and Knoll, A.H., 2000, Calcified metazoans in thrombolite-stromatolite reefs of the terminal Proterozoic Nama Group, Namibia: Paleobiology, v. 26, p. 334-359.

Hallam, A., 1998, Mass extinctions in Phanerozoic time, in Grady, M.M., Hutchison, R., McCall, G.J.H., and Rothery, D.A., eds., Meteorites: Flux with Time and Impact Effects: Geological Society Special Publications, v. 140, p. 259 274.

Hammer, Ø, Harper, D.A.T., and Ryan, P.D., 2001, PAST: Paleontological statistics software package for education and data analysis: Palaeontologica Electronica, v. 4, no. 1, art. 4, $178 \mathrm{~KB}$, http://palaeo-electronica.org/2001_1/past/issue1_01.htm (checked October 20, 2009).

Harney, J.N., 2003, A budget of carbonate framework and sediment production, Kailua Bay, Oahu, Hawaii: Journal of Sedimentary Research, v. 73, p. 856-868.

Hersi, O.S., Lavoie, D., and Nowlan, G.S., 2002, Stratigraphy and sedimentology of the Upper Cambrian Strites Pond Formation, Philipsburg Group, Southern Quebec, and implications for the Cambrian platform in eastern Canada: Bulletin of Canadian Petroleum Geology, v. 50, p. 542-565.

Higgins, J.A., Fischer, W.W., and Schrag, D.P., 2009, Oxygenation of the oceans and sediments: Consequences for the seafloor carbonate factory: Earth and Planetary Sciences, v. 284, p. 25-33.

Hintze, L.F., 1973, Lower and Middle Ordovician stratigraphic sections in the Ibex area, Millard County, Utah: Brigham Young University Geology Studies, v. 20, p. $3-36$.

Hodych, J.P., Cox, R.A., and Koster, J., 2004, An equatorial Laurentia at $550 \mathrm{Ma}$ confirmed by Grenvillian inherited zircons dated by LAM ICP-MS in the Skinner Cove volcanics of western Newfoundland: Implications for inertial interchange true polar wander: Precambrian Research, v. 129, p. 93-113.

Horita, J., Zimmerman, H., and Holland, H.D., 2002, Chemical evolution of sea water during the Phanerozoic: Implications from the record of marine evaporites: Geochimica et Cosmochimica Acta, v. 66, p. 3733-3756.

Hotinski, R.M., Kump, L.R., and Arthur, M.A., 2004, The effectiveness of the Paleoproterozoic biological pump: d13C gradients from platform carbonates of the Pethei Group (Great Slave Lake Supergroup, N.W.T.): Bulletin of the Geological Society of America, v. 116, p. 539-554.

Hough, M.L., Shields, G., Evins, L.Z., Strauss, H., Henderson, R.A., and MackenZIE, S., 2006, A major sulphur isotope event at c. 510 Ma: A possible anoxia-extinction-volcanism connection during the Early-Middle Cambrian transition: Terra Nova, v. 18, p. 257-263.

Howley, R.A., 2002, Analysis of cyclic shallow-water carbonates: Cambrian Highland Peak Formation, eastern Nevada: Unpublished M.S. thesis, University of Nevada, Las Vegas, 254 p.
Hurtgen, M.T., Pruss, S.B., and Knoll, A.H., 2009, Evaluating the relationship between the carbon and sulfur cycles in the later Cambrian ocean: An example from the Port au Port group, western Newfoundland, Canada: Earth and Planetary Science letters, v. 281, p. 288-297.

JAAnusson, V., 1972, Constituent analysis of an Ordovician limestone: Lethaia, v. 5, p. $217-237$.

JAmes, N.P., and Stevens, R.K., 1982, Anatomy and evolution of a Lower Paleozoic continental margin, western Newfoundland, in Excursion 2B, 11th International Congress on Sedimentology, 22-27 August 1982, Hamilton, Ontario, Canada: International Association of Sedimentologists, Hamilton, 75 p.

James, N.P., Stevens, R.K., Barnes, C.R., and Knight, I., 1989, Evolution of a Lower Paleozoic continental-margin carbonate platform, northern Canadian Appalachians, in Crevello, P.D., Wilson, J.L., Sarg, J.F., and Read, J.F., eds., Controls on Carbonate Platform and Basin Development: SEPM Special Publication, Tulsa, Oklahoma, v. 44, p. 123-146.

Ji, Z., and Barnes, C.R., 1994, Lower Ordovician conodonts of the St. George Group, Port au Port Peninsula, western Newfoundland, Canada: Palaeontographica Canadiana, v. 11, p. 1-149.

JoLIfFe, I.T., 2002, Principal Components Analysis. 2nd Edition. Springer, New York, $487 \mathrm{p}$.

Johns, R.A., 1995, The good, the bad and the ugly: The paleoecology of Ordovician sponge/algal reef mounds, in Cooper, J.D., Droser, M.L., and Finney, S.C., eds., Ordovician Odyssey: Short Papers for the 7th International Symposium on the Ordovician System: Pacific Section, Society for Sedimentary Geology (SEPM), FullertonCalifornia, p. 429-433.

KiERnAN, J.P., 1999, Lithostratigraphy, sedimentology and diagenesis of the Upper Ordovician Hull Beds and Verulam Formation, Upper Ottawa Group, Eastern Ontario: Unpublished M.S. thesis, Carleton University, Ottawa, 297 p.

Kleypas, J., Buddemeier, R.W., Archer, D., Gattuso, J.P., Langdon, C., and OpDYKe, B.N., 1999, Geochemical consequences of increased atmospheric carbon dioxide on coral reefs: Science, v. 284, p. 118-120.

KNight, I., and JAmes, N.P., 1987, The stratigraphy of the Lower Ordovician St. George Group, western Newfoundland: The interaction between eustasy and tectonics: Canadian Journal of Earth Sciences, v. 24, p. 1927-1951.

KNoll, A. H., 2003, Biomineralization and evolutionary history, in Dove, P.A., Yoreo, J.D., and Weiner, S., eds., Biomineralization: Mineralogical Society of America, Washington, DC, p. 329-356.

Koerschner, W.F., and Read, J.F., 1989, Field and modeling studies of Cambrian carbonate cycles, Virginia Appalachians: Journal of Sedimentary Petrology, v. 59, p. $654-687$.

Langdon, C., And Atkinson, M.J., 2005, Effect of elevated $\mathrm{pCO}_{2}$ on photosynthesis and calcification of corals and interactions with seasonal change in temperature/ irradiance and nutrient enrichment: Journal of Geophysical Research, v. 110, 16 p., C09S07, doi:10.1029/2004JC002576.

LI, X., 1998, The development of early Paleozoic shell concentrations: Evidence from the Basin and Range Province of the western United States (California, Nevada and Utah): Unpublished Ph.D. dissertation, University of California at Riverside, Riverside, $268 \mathrm{p}$.

Li, X., and Droser, M.L., 1997, Nature and distribution of Cambrian shell concentrations: Evidence from the Basin and Range Province of the western United States (California, Nevada, and Utah): PALAIOS, v. 12, p. 111126.

Li, X., and Droser, M.L., 1999, Lower and Middle Ordovician shell beds from the Basin and Range province of the western United States (California, Nevada, and Utah): PALAIOS, v. 14, p. 215-233.

Li, Y.-H., Takahashi, T., AND Broecker, W.S., 1969, Degree of saturation of $\mathrm{CaCO}_{3}$ in the oceans: Journal of Geophysical Research, v. 74, p. 5507-5525.

Mángano, M.G., and Droser, M.L., 2004. The ichnologic record of the Ordovician radiation, in Webby, B.D., Paris, F., Droser, M.L., and Percival, I.G., eds., The Great Ordovician Biodiversification Event: Columbia University Press, New York, p. $369-379$.

MCDowell, R.R., 1987, Paleogeography, depositional environments, and petroleum potential of the Middle Ordovician Kanosh Formation: Unpublished Ph.D. dissertation, Colorado School of the Mines, Golden, $410 \mathrm{p}$.

Miller, A.I., and Foote, M., 1996, Calibrating the Ordovician radiation of marine life: Implications for Phanerozoic diversity trends: Paleobiology, v. 22, p. 304-309.

Miller, A.I., and Mao, S., 1995, Association of orogenic activity with the Ordovician radiation of marine life: Geology, v. 23, p. 305-308.

Miller, J.F., Evans, K.R., Loch, J.D., Ethington, R.L., Stitt, J.H., Holmer, L., and Popov, L.E., 2003, Stratigraphy of the Sauk III Interval (CambrianOrdovician) in the Ibex area, western Millard County, Utah and central Texas: Geology Studies, v. 47, p. 23-118.

Montañez, I.P., and Droser, M.L., 1991, Use of cycle stacking patterns to define third-order depositional sequences: Middle to Late Cambrian Bonanza King Formation, southern Great-Basin, in Annual Meeting of the AAPG, Dallas, Texas: AAPG Bulletin, v. 75, n. 3, p. 638-639. 
Morse, J.W., Arvidson, R.S., and LütTge, A., 2007, Calcium carbonate formation and dissolution: Chemical Reviews, v. 107, p. 342-381.

Obst, M., Wehrli, B., and DitTrich, M., 2009, $\mathrm{CaCO}_{3}$ nucleation by cyanobacteria: Laboratory evidence for a passive, surface-induced mechanism: Geobiology, v. 7, p. 324-347.

Osleger, D.A., and Montañez, I.P., 1996, Cross-platform architecture of a sequence boundary in mixed siliciclastic-carbonate lithofacies, middle Cambrian, southern Great Basin, USA: Sedimentology, v. 43, p. 197-217.

Patzkowsky, M.E., and Holland, H., 1993, Biotic response to a Middle Ordovician radiation paleoceanographic event in eastern North America: Geology, v. 21, p. 619-622.

Payne, J. L., Lehrmann, D.J., Wei, J., and Knoll, A.H., 2006, The pattern and timing of biotic recovery from the end-Permian mass extinction on the Great Bank of Guizhou, Guizhou Province, south China: PALAIOS, v. 20, p. 63-85.

Peters, S.E., 2005a, Sepkoski's online genus database. July 2005, supplement to Sepkoski (2002), http://strata.geology.wisc.edu/jack/. Checked October 20, 2009.

Peters, S.E., 2005b, Geologic constraints on the macroevolutionary history of marine animals: Proceedings of the National Academy of Sciences, U.S.A., v. 102, p. 12326-12331.

Peters, S.E., 2006, Macrostratigraphy of North America: Journal of Geology, v. 114, p. $391-412$.

Peters, S.E., 2007, The problem with the Paleozoic: Paleobiology v. 33, p. 165-181.

Peterson, K.J., 2005, Macroevolutionary interplay between planktic larvae and benthic predators: Geology, v. 33, p. 929-932.

Petrychenko, O.Y., Peryt, T.M., And Chechel, E.I., 2005, Early Cambrian seawater chemistry from fluid inclusions in halite from Siberian evaporites: Chemical Geology, v. 219, 149-161.

Pörtner, H.O., 2001, Climate change and temperature-dependent biogeography: Oxygen limitation and thermal tolerance in animals: Naturwissenschaften, v. 88, p. 137-146.

Pörtner, H.O., Langenbuch, M., and Reipschläger, A., 2004, Biological impact of elevated ocean $\mathrm{CO}_{2}$ concentrations: Lessons from animal physiology and earth history: Journal of Oceanography, v. 60, p. 705-718.

Pratt, B.R., and James, N.P., 1982, Cryptalgal-metazoan bioherms of early Ordovician age in the St. George Group, western Newfoundland: Sedimentology, v. 29 , p. $543-569$.

Pratt, B.R., and James, N.P., 1986, The St. George Group (Lower Ordovician) in western Newfoundland: Tidal flat island model for carbonate sedimentation in shallow epeiric seas: Sedimentology, v. 33, p. 313-343.

Raiswell, R., and Berner, R.A., 1986, Pyrite and organic matter in Phanerozoic normal marine shales: Geochimica et Cosmochimica Acta, v. 50, p. 1967-1976.

Ridgwell, A., and Zeebe, R.E., 2005, The role of the global carbonate cycle in the regulation and evolution of the Earth system: Earth and Planetary Science Letters, v. 234 , p. 299-315.

Rohr, D.M., Measures, E.A., Boyce, W.D., and Knight, I., 2001, Early Ordovician gastropods of the Barbace Cove Member (Boat Harbor Formation) and Catoche Formation, western Newfoundland, in Pereira, C.P.G., and Walsh, D.G., eds., Current Research, Geological Survey of Newfoundland and Labrador: Geological Survey, Department of Mines and Energy, St. John's, p. 113-126.

Ross, R.J., 1977, Ordovician paleogeography of the western United States, in Stewart, J.H., Stevens, C.H., and Fritsche, A.E., eds., Paleozoic Paleogeography of the Western United States: Pacific Coast Paleogeography Symposium 1, Pacific Section, Society of Economic Paleontologists and Mineralogists (SEPM), Long Beach, California, v. 7, p. 19-38.

Ross, R.J., 1995, Mid-symposium field trip: Las Vegas to Meiklejohn Peak near Beatty, Nevada, in Cooper, J., ed., Ordovician of the Great Basin: Field Trip Guidebook and Volume for the Seventh International Symposium of the Ordovician System (Las Vegas): Pacific Section, SEPM (Society of Sedimentary Geology), Fullerton, California, v. 78, p. 51-62.

Ross JR., R.J., James, N.P., Hintze, L.F., and Poole, F.G., 1989, Architecture and evolution of a Whiterockian (early Middle Ordovician) carbonate platform, Basin Ranges of western U.S.A., in Crevello, P.D., Wilson, J.L., Sarg, J.F., and Read, J.F., eds., Controls on Carbonate Platform and Basin Development: SEPM
(Society for Sedimentary Geology) Special Publication, Tulsa, Oklahoma, v., 44, p. 167-185.

Ross, R.J., Hintze, L.H., Ethington, L., Miller, J.F., TAYlor, M.E., and Repetski, J.E., 1997, The Ibexian, lowermost series in the North American Ordovician, with a section of echinoderm biostratigraphy by Sprinkle, J., and Guensberg, T.E., in Taylor, M.E., ed., Early Paleozoic Biochronology of the Great Basin, Western United States: U.S. Geological Survey Professional Paper, p. 1-50.

Rowland, S.M., and SHAPIRo, R.S., 2002, Reef patterns and environmental influences in the Cambrian and earliest Ordovician, in Kiessling, W., Flügel, E., and Golonka, J., eds., Phanerozoic Reef Patterns: SEPM (Society for Sedimentary Geology) Special Publication, Tulsa, Oklahoma, v. 72, p. 95-128.

Saltzman, M.R., Cowan, C.A., Runkel, A.C., Runnegar, B., Stewart, M.C., and Palmer, A.R., 2004, The Late Cambrian SPICE event and the Sauk II-Sauk III regression: New evidence from Laurentian basins in Utah, Iowa, and Newfoundland: Journal of Sedimentary Research, v. 74, p. 366-377.

Schmitz, B., Harper, D.A.T., Peucker-Ehrenbrink, B., Stouge, S., Alwark, C., Cronholm, A., Bergström, S.M., Tassinari, M., and Wang, X., 2008, Asteroid breakup linked to the Great Ordovician Biodiversification Event: Nature Geoscience, v. 1, p. 49-53.

Sepkoski, J.J., 1977, Dresbachian (Upper Cambrian) stratigraphy in Montana, Wyoming, and South Dakota: Unpublished Ph.D. dissertation, Harvard University, Cambridge, 563 p.

Sepkoski JR., J.J., 1978, A kinetic model of Phanerozoic taxonomic diversity I: Analysis of marine orders: Paleobiology, v. 4, p. 223-251

SePKoski JR., J.J., 1982, Flat-pebble conglomerates, storm deposits, and the Cambrian bottom fauna, in Einsele, G., and Seilacher, A., eds., Cyclic and Event Stratification: Springer-Verlag, Berlin, p. 371-385.

Sepkoski JR., J.J., 2002, A compendium of fossil marine animal genera: Bulletin of American Paleontology, v. 363, p. 1-560.

Sepkoski, J.J., Bambach, R.K., and Droser, M.L., 1991, Secular changes in Phanerozoic event bedding and the biological imprint, in Einsele, G., Ricken, W., Seilacher, A., eds., Cycles and Events in Stratigraphy: Springer-Verlag, Berlin, p. 298-312.

Servais, T., Harper, D.A.T., Li, J., Munnecke, A., Owen, A.W., and Sheehan, P.M., 2009, Understanding the Great Ordovician Biodiversification Event (GOBE): Influences of paleogeography, paleoclimate, or paleoecology?: GSA Today, v. 19, no. 4-5, p. 4-10.

Servais, T., Lehnert, O., Li, J., Mullins, G.L., Munnecke, A., Nützel, A., and Vecoli, M., 2008, Ordovician biodiversification: Revolution in the oceanic trophic chain, Lethaia, v. 41, p. 99-109.

Smith, A.G., 2001, Paleomagnetically and tectonically based global maps, in Zhuravlev, A.Y., and Riding, R., eds., The Ecology of the Cambrian Radiation: Columbia University Press, New York, p. 11-46.

Smith, G.L., Byers, C.W., and Dott JR., R.H., 1993, Sequence stratigraphy of the Lower Ordovician Prairie du Chien Group on the Wisconsin Arch and in the Michigan Basin: AAPG Bulletin, v. 77, p. 49-67.

Trotter, J.A., Williams, I.S., Barnes, C.R., Lecuyer, C., and Nicoll, R.S., 2008, Did cooling oceans trigger Ordovician biodiversification?: Evidence from conodont thermometry: Science, v. 321, p. 550-554.

Webby, B.D., Paris, F., Droser, M.L., and Percival, I., 2004, The Great Ordovician Biodiversification Event: Columbia University Press, New York, 484 p.

Westrop, S.R., 1992, Upper Cambrian (Marjuman-Steptoean) trilobites from the Port Au Port Group, Western Newfoundland: Journal of Paleontology, v. 66, p. $228-255$.

Wood, R.A, Grotzinger, J.P., and Dickson, J.A.D. 2002, Proterozoic modular biomineralized metazoan from the Nama Group, Namibia: Science, v. 296, p. 2383-2386.

Zeebe, R.E., and Westbroek, P., 2003, A simple model for the $\mathrm{CaCO}_{3}$ saturation state of the ocean: The "Strangelove," the "Neritan," and the "Cretan" ocean: Geochemistry, Geophysics, Geosystems, v. 4, p. 1-26.

Zhuravlev, A.Y., and Wood, R.A., 1996, Anoxia as the cause of the late Early Cambrian extinction: Geology, v. 24, p. 311-314.

\section{ACCEPTED SEPTEMBER 28, 2009}

